\title{
REGULATING HidDEN RiSKS TO CONSERVATION LANDS IN RESOURCE RICH AREAS
}

\author{
REBECCA NELSON*
}

\begin{abstract}
Australia leads the world in formally dedicating private land to environmental conservation, helping governments protect critical biodiversity without straining the public purse. In Queensland, the booming resources sector threatens this biodiversity protection, even beyond landholders' well-recognised lack of veto power over mining approvals on their land. Three structural legal biases increase this vulnerability. To differing degrees, Queensland's laws assume that mining affects only land under or adjoining mining tenures, overlooking scientifically likely longer-distance impacts ('boundary bias'); they emphasise protecting built and commercial infrastructure over ecological assets, overlooking significant investment in species and ecosystems ('infrastructure bias'); and they allow consideration of proposed mining in isolation, without considering cumulative impacts on ecological assets ('singularity bias'). Fortunately, Queensland law and policy precedents suggest potential corrective reforms.
\end{abstract}

\section{INTRODUCTION}

When one thinks about environmental conservation and wilderness, national parks and other public lands tend to come to mind. Less well known, but increasingly vital, are privately owned conservation lands. These lands represent the offspring of a union between public interest environmental conservation and private property. In 2021, the concept marks its $70^{\text {th }}$ birthday in Australian law, ${ }^{1}$ and almost 200 years in use abroad, ${ }^{2}$ having also achieved recognition in

\footnotetext{
BE(Environmental) (Hons), LLB (Hons) (Melb); JSM, JSD (Stanford); Associate Professor, Melbourne Law School, The University of Melbourne. This work is based on research funded by the Australian Research Council (\#DE180101154). The article benefited from early conversations with Rebecca Spindler, Jody Gunn, Moya Tomlinson, Cecilia Riebl and Nicholas Ryugo, thoughtful feedback from Revel Pointon, Amanda Cravens, Nicola Ulibarri and Anne Siders, helpful comments from three anonymous reviewers, and research assistance from Lucas Volfneuk. Disclosure of interests: the author is a volunteer non-executive director of Bush Heritage Australia, which owns and manages land for conservation purposes in Queensland. The views expressed here are those of the author and not necessarily those of any organisation. All errors remain those of the author. Mathew J Hardy et al, 'Exploring the Permanence of Conservation Covenants' (2017) 10(2) Conservation Letters 221, 224 (referring to Australia's first conservation covenant established in 1951 in NSW).

Leticia Ochoa-Ochoa et al, 'The Effects of Governmental Protected Areas and Social Initiatives for Land Protection on the Conservation of Mexican Amphibians' (2009) 4(9) PLoS ONE e6878, 1-9, 2.
} 
international legal regimes. ${ }^{3}$ Under these arrangements, private landholders agree, and are legally bound under, agreements, covenants or other similar arrangements, ${ }^{4}$ to manage their property for ecological outcomes 5 ('private conservation land'). Private conservation land is thus a conceptual sibling to important environmental mechanisms like carbon and biodiversity offsets, which create private value for land management in the public interest, and cousin to environmental policy concepts like 'natural capital' and ecosystem services, ${ }^{6}$ which encourage valuing nature through the lens of markets, assets, capital, and property. Yet, increasing reliance on these concepts, and widespread national and international enthusiasm for them, ${ }^{7}$ have not necessarily been accompanied by meaningful protections usually associated with assets and capital. This is especially clear in the case of conflicts with incompatible land uses that have the potential to impair conservation outcomes on private conservation land, including some Indigenous protected areas. ${ }^{8}$ As governments increasingly encourage and rely on private conservation lands to deliver environmental conservation in the public interest, the growth of conflicting land uses has emerged as a serious problem for legal and regulatory resolution. Resolving this problem would not only better protect conservation outcomes, but it would also benefit other rural landholders and public conservation lands. ${ }^{9}$

Conference of the Parties to the Convention on Biological Diversity, Ecosystem Conservation and Restoration, $12^{\text {th }} \mathrm{mtg}$, UN Doc UNEP/CBD/COP/DEC/XII/29 (17 October 2014) 107 [2] (recognising the importance of private protected areas in biodiversity conservation and sustainable ecosystem management).

These agreements have diverse names across different jurisdictions, including conservation covenants, conservation easements, private protected areas, nature sanctuaries, and voluntary conservation use areas: Heather Bingham et al, 'Privately Protected Areas: Advances and Challenges in Guidance, Policy and Documentation' (2017) 23(1) Parks 13, 15-17. The extent to which, and the ways in which, the owner is legally bound, vary with the terms of the specific agreement.

5 For a range of jurisdictional approaches to implementation of the concept, see Law Commission No 349, Conservation Covenants (Report, 2014) (recommending statutory establishment of conservation covenants in England and Wales).

$6 \quad$ See generally Colin T Reid and Walters Nsoh, The Privatisation of Biodiversity?: New Approaches to Conservation Law (Edward Elgar, 2016); Natural Resource Management Ministerial Council, Australia's Biodiversity Conservation Strategy 2010-2030 (2010) 3, 10; Carbon Credits (Carbon Farming Initiative) Act 2011 (Cth).

$7 \quad$ For recent examples, see, eg, Greening Australia, Year in Review 2019 (Report, 2019) 5 <https://www.greeningaustralia.org.au/wp-content/uploads/2020/01/CKA9866_GA.YearIn Review2019_LINKS_S.pdf>; KPMG and National Farmers Federation, A Return on Nature: Enabling the Market for Sustainable Finance and Ecosystem Services (Report, December 2019); Food and Agriculture Organisation of the United Nations, 'Ecosystem Services \& Biodiversity' (Web Page, 2021) <http://www.fao.org/ecosystem-services-biodiversity/en/>.

See below $n 26$.

Similar problems of conflict are also likely to arise in the context of Aboriginal and Torres Strait Islander values associated with elements of the environment. These values are distinct from, though overlap in some respects with, Western ecological values. This context involves additional important legal regimes that lie outside the scope of this paper to discuss, for example native title and cultural heritage laws, which warrant dedicated and sustained future attention. 
Australia now has the largest area of private conservation lands in the world, ${ }^{10}$ and areas are increasing rapidly. ${ }^{11}$ This growth is occurring in the shadow of increasing potential conflict between conservation lands and a booming resources sector that is thirsty for water, especially groundwater. At the same time, scientific knowledge has grown about the needs of key ecological assets including water needs - and the ways that mines, gas developments and other extractive activities can affect groundwater conditions over wider distances than previously thought. ${ }^{12}$ Queensland epitomises the uncomfortable intersection of these trends: government policy promotes mining as economically critical while simultaneously seeking to expand private protected areas and investing in ecological water science. ${ }^{13}$ Some conflicts at this intersection end in court. ${ }^{14}$ Recent reforms to conservation laws try to address the potential for conflict. ${ }^{15}$ However, these laws equally raise questions for private conservation landholders, environmentalists, and government as an investor in conservation, about the need for more thorough protections.

The tensions epitomised in Queensland arise around Australia ${ }^{16}$ and seem likely to grow. Climate change will likely increase water and ecological stress ${ }^{17}$ as the pandemic threatens to shrink public resources available to expand public conservation lands like national parks, and governments encourage private conservation to fill the breech. Risks to conservation lands may well increase as governments 'fast-track' resources projects to restart stuttering post-pandemic economies. ${ }^{18}$ Environmental offsets - often secured by, and therefore reliant on,

Bingham et al (n 4) 19.

Hardy et al (n 1) 222.

See discussion in Part IIC.

See discussion in Parts IIA, C.

See, eg, Oakey Coal Action Alliance Inc v New Acland Coal Pty Ltd (2021) 386 ALR 212 (with earlier litigation leading to this appeal focusing on groundwater-related impacts of mining on landscapes); Hancock Coal Pty Ltd $v$ Kelly and Department of Environment and Heritage Protection (No 4) [2014] QLC 12 ('Hancock Coal').

15 The Nature Conservation (Special Wildlife Reserves) and Other Legislation Amendment Act 2019 (Qld) establishes a new form of private protected area, the 'special wildlife reserve', specifically intended to 'allow for the protection of lands of outstanding conservation value from incompatible land uses': Explanatory Notes, Nature Conservation (Special Wildlife Reserves) and Other Legislation Amendment Bill 2018 (Qld) 1. See also Parts IIIB2, D2.

16 In South Australia see, eg, Alexandra Wawryk, 'Conservation and Access to Land for Mining in Protected Areas: The Conflict Over Mining in South Australia's Arkaroola Wilderness Sanctuary' (2014) 26(2) Journal of Environmental Law 291, and in Western Australia see, eg, Paul Vogel, 'The Balance between Mining and Conservation', ABC News (online, 18 November 2013) <https://www.abc.net.au/news/2013-11-18/vogel-mining-conservation-balance/5099404>.

${ }_{17}$ Olivia Woolley, 'What Would Ecological Climate Change Law Look Like? Developing a Method for Analysing the International Climate Change Regime from an Ecological Perspective' (2020) 29(1) Review of European, Comparative and International Environmental Law 76, 78-80.

18 Scott Morrison, 'Address to the Committee for Economic Development of Australia 15 June 2020', (Address, CEDA's State of the Nation Conference, 15 June 2020) <https://www. pm.gov.au/media/address-\%E2\%80\%93-ceda\%E2\%80\%99s-state-nation-conference>. 
private conservation land ${ }^{19}$ - will likely grow with new resources developments and voluntary markets driven by climate change concerns. After 70 years, deeper legal reform is needed to support increasing reliance on private property that is used to produce public benefit ecological outcomes.

Part II of this article briefly reviews the rise of private conservation lands, the growing resources sector, and scientific knowledge about groundwater conditions and impacts in general and with respect to Queensland. Part III undertakes detailed statutory analysis to explore the key ways in which private conservation lands in Queensland are vulnerable to the impacts of resources activities, focusing on groundwater. It identifies three categories of structural legal biases - implicit assumptions that run through a complex system of laws and act as blinkers to exclude important considerations - that give rise to important vulnerabilities for private conservation lands, with a focus on groundwater. Part IV investigates ways to strengthen protections for private conservation lands both through law reform and using existing laws. Part V concludes.

\section{BACKGRound: CONSERVATION LANDHOLDERS, Miners, AND SCIENTISTS}

\section{A The Rise of Private Conservation}

Landscape-scale conservation is critical to safeguarding species and ecosystems as climate change threatens to change their distributions. ${ }^{20}$ Unfortunately, public protected lands are often fragmented and do not comprehensively represent species and ecosystems, with 'the overwhelming majority of poorly represented biodiversity features occurring primarily on private land' ${ }^{21}$ Scientists have urged an expansion to private conservation lands to deal with problems of representativeness and fragmentation in public conservation lands. ${ }^{22}$

Over their 70-year history in Australia, private conservation areas have been established in every State and Territory, ${ }^{23}$ and both governments and non-

19 See, eg, the BioBanking, BushBroker and Conservation Banking schemes explained in Irene Alvarado-Quesada, Lars Hein and Hans-Peter Weikard, 'Market-Based Mechanisms for Biodiversity Conservation: A Review of Existing Schemes and an Outline for a Global Mechanism' (2014) 23(1) Biodiversity and Conservation 1, 7-8. See also Reid and Nsoh (n 6) 6, 184, 189-90. Department of Environment and Science (Qld), Queensland's Protected Areas Strategy 2020-2030: Protecting Our World-Class Natural and Cultural Values (2020) 13 ('Queensland's Protected Areas Strategy 2020-2030').

${ }_{21}$ Ielyzaveta M Ivanova and Carly N Cook, 'The Role of Privately Protected Areas in Achieving Biodiversity Representation within a National Protected Area Network' (2020) 2(12) Conservation Science and Practice e307:1-12, 7.

Ibid.

23 See generally Hardy et al (n 1) 224, 225. 
government organisations have embraced the concept. ${ }^{24}$ Queensland hosts Australia's largest private protected lands network, accounting for 31 per cent of the state's protected lands by area, and protecting ecosystems found only on private land. ${ }^{25}$ Diverse landholders own these lands, from Aboriginal and Torres Strait Islander peoples, to hobby farmers, to national environmental NGOs, to the nation's largest pastoral company. ${ }^{26}$ Recent government strategy aims to 'accelerate' conservation landholdings using 'investment partnerships' and 'strategic incentives', ${ }^{27}$ highlighting the importance of ensuring genuine and reliable protection for these lands.

As biodiversity protection increasingly relies on private lands, risks to these lands threaten Australian biodiversity as a whole. Globally, ${ }^{28}$ and in Australia, ${ }^{29}$ mining directly on and under conservation areas is known to be a serious threat to these areas. ${ }^{30}$ It is perhaps less well known that mining outside the boundaries of conservation lands is a threat of significant concern for private conservation. In Queensland, local advocacy groups and conservation landholders have brought legal challenges against mines, ${ }^{31}$ facing the threat of being bankrupted by litigation costs in the process. ${ }^{32}$ Mining may also pose a more indirect threat to conservation and climate change mitigation if it affects ecosystems subject to biodiversity and carbon market mechanisms, 33 which fund management of some conservation land. Mining-related threats may also disincentivise philanthropic

See, eg, WWF Australia, Regenerate Australia: A Roadmap to Recovery and Regeneration (Prospectus, October 2020) 14 (contemplating a 'Land Fund to create new private native species arks'). Queensland's Protected Areas Strategy 2020-2030 (n 20) 6.

26 Katie Moon and Chris Cocklin, 'Participation in Biodiversity Conservation: Motivations and Barriers of Australian Landholders' (2011) 27(3) Journal of Rural Studies 331, 336; Queensland's Protected Areas Strategy 2020-2030 (n 20) 21 (referring to the ownership of Queensland's largest nature refuge by Queensland's largest pastoral company). Examples of Aboriginal ownership of land covered by a nature refuge are the Jamba Dhandan Duringala Indigenous Protected Area: Nature Conservation (Protected Areas) Regulation 1994 (Qld) sch 5; 'Jamba Dhandan Duringala IPA', National Indigenous Australians Agency (Web Page) <https://www.niaa.gov.au/indigenousaffairs/environment/jamba-dhandan-duringala-ipa> and the Olkola Nature Refuge: Nature Conservation (Protected Areas) Regulation 1994 (Qld) sch 5; Cameron Atfield, 'Cape York Land Handed Back to Traditional Olkola Owners', Brisbane Times (online, 6 December 2014) $<$ https://www.brisbanetimes.com.au/national/queensland/cape-york-land-handed-back-totraditional-olkola-owners-20141206-121q87.html>. Queensland's Protected Areas Strategy 2020-2030 (n 20) 19, 21, 22. See generally Rachel E Golden Kroner et al, 'The Uncertain Future of Protected Lands and Waters' (2019) 364(6443) Science 881.

29 See generally Philippa England, 'Conservation Covenants: Are They Working and What Have We Learned?' (2015) 34(1) University of Tasmania Law Review 92; Wawryk (n 16).

30 See generally Wawryk ( $\mathrm{n}$ 16); Vanessa M Adams and Katie Moon, 'Security and Equity of Conservation Covenants: Contradictions of Private Protected Area Policies in Australia' (2013) 30(1) Land Use Policy 114. Other threats may also be internal to conservation reserves. For concerns about landholder behaviour, trespassers, and the adequacy of monitoring: see, eg, Hardy et al (n 1) 225, 227; England (n 29) 103-4.

See, eg, Waratah Coal Pty Ltd $v$ Youth Verdict Ltd [2020] QLC 33.

See, eg, New Acland Coal Pty Ltd $v$ Oakey Coal Action Alliance Inc [2020] QSC 212, [55].

Queensland's Protected Areas Strategy $2020-2030$ (n 20) 14, 21. Owners of nature refuges may apply for rights to deal with carbon abatement products on the land: Nature Conservation Act 1992 (Qld) S 39F ('Nature Conservation Act'). 
investment in conservation. ${ }^{34}$ These concerns are serious enough to have attracted legislative attention: mining is forbidden on lands protected by Queensland's newly created 'special wildlife reserve' mechanism - the only such protection for private conservation lands in Australia. 35 This protection is intended, at least in part, to attract national and international investment to Queensland by conservation organisations. ${ }^{36}$ Even so, like the nature refuges that comprise most of Queensland's private conservation lands, special wildlife reserves may be affected by resources activities outside their boundaries - the focus of this article.

\section{B The Growth and Facilitation of Resources Activities and Their Water Use}

As private conservation has grown, resources activities have also increased. The gross state product of mining in Queensland has increased from AUD3.8 billion in 1989-90 to AUD39.2 billion in 2019-20.37 Globally, economic goals to facilitate resources activities have triggered legislative attempts to 'streamline' regulations, a trend that seems likely to increase further with post-pandemic economic recovery strategies. ${ }^{38}$ These 'streamlining' trends are problematic in the light of the clear risks that mining activities can pose to biodiversity at the site, regional and global scales. ${ }^{39}$ Regional and cumulative environmental impacts of mines 'have received little attention'.40 This is unsurprising given that regulatory approval processes tend to focus on the mine's direct impacts on the site of extraction. ${ }^{41}$ By contrast, analysing cumulative effects means considering where 'impact zones' overlap. The proximity of a mine to a valued ecosystem is 'not the decisive factor' 42 to its significance, and assuming that an ecosystem is

Queensland's Protected Areas Strategy 2020-2030 (n 20) 35.

Nature Conservation Act (n 33) s 27; Queensland Government, 'Special Wildlife Reserves', Private Protected Areas (Web Page, 25 January 2021) < https://www.qld.gov.au/environment/parks/ protected-areas/private/special-wildlife-reserves $>$.

Queensland's Protected Areas Strategy 2020-2030 (n 20) 20.

Australian Bureau of Statistics, Australian National Accounts: State Accounts 2019-2020 (Catalogue No 5220.0, 20 November 2020).

See, eg, Executive Office of the President, Accelerating the Nation's Economic Recovery from the COVID-19 Emergency by Expediting Infrastructure Investments and Other Activities (Executive Order 13927, 4 June 2020) <https://www.federalregister.gov/documents/2020/06/09/202012584/accelerating-the-nations-economic-recovery-from-the-covid-19-emergency-byexpediting-infrastructure>. For Queensland's approach to streamlining, see discussion of the State Development and Public Works Organisation Act 1971 (Qld), below in Part IIIC2.

See generally Laura J Sonter, Saleem H Ali and James E M Watson, 'Mining and Biodiversity: Key Issues and Research Needs in Conservation Science' (2018) 285(1892) Proceedings of the Royal Society B: Biological 1.

Ibid 2.

Ibid 3.

Council on Environmental Quality (United States), Considering Cumulative Effects under the National Environmental Policy Act (Report, 1997) 17 ('Considering Cumulative Effects under the NEPA'). 
safe from the impacts of a relatively distant mine overlooks potentially significant 'long-range' risks.

Water use is an important pathway by which mines may cause off-site cumulative environmental effects. ${ }^{43}$ Resources developments may use water intentionally, for activities such as dewatering, dust suppression and processing. ${ }^{44}$ Water use may also be unintentional but unavoidable: in the case of coal seam gas extraction, groundwater is an unavoidable by-product of extracting the gas over the life of the operation; 45 in the case of a mine void, water is 'used' as it flows into and evaporates from the mine void in perpetuity. ${ }^{46}$ Although mining uses only around $15 \%$ of global water use, and $4 \%$ of water use in Australia (mostly through coal mining), ${ }^{47}$ there is significant variation in the water efficiency of mining operations. ${ }^{48}$ Groundwater impacts can also propagate long distances, causing declining groundwater levels tens of kilometres away from the tenure site. ${ }^{49}$ Legislatures, litigants and the media are becoming increasingly aware of the potential for mine water use to cause severe ecological damage in some local areas..$^{50}$

\section{Scientific Knowledge about Ecological Dependence on Groundwater}

A wide range of species and ecosystems - from streams receiving baseflow, to desert springs, to terrestrial forests and even cave-dwelling microfauna depend on groundwater for all or part of their water needs. ${ }^{51}$ These 'groundwater dependent ecosystems' ('GDEs') have an increasing profile in law and policy, in line with increasing focus on 'environmental flows' in the surface water context. ${ }^{52}$

See generally J Sreekanth et al, 'Regional-Scale Modelling and Predictive Uncertainty Analysis of Cumulative Groundwater Impacts from Coal Seam Gas and Coal Mining Developments' (2020) 28(1) Hydrogeology Journal 193.

See generally Wendy A Timms, Sudeep Nair and Rebecca Nelson, 'More Joules Per Drop: How Much Water Does Unconventional Gas Use Compared to Other Energy Sources and What Are the Legal Implications?' (2019) 36(5) Environmental and Planning Law Journal 565.

Sreekanth et al (n 3) 194. See also Department of Environment and Science (Qld), 'Coal Seam Gas Water', Water (Web Page, 28 June 2021) <https://environment.des.qld.gov.au/management/ activities/non-mining/water/csg-water>.

Hancock Coal (n 14) [197].

Timms et al (n 4) 566-7.

Ibid 568.

See, eg, below $n 1688$ and accompanying text.

See, eg, above nn 31-32 and accompanying text; Richard Baker, 'South Australia's Disappearing Springs Raise Questions for Miner BHP', The Age (online, 23 November 2020) $<$ https://www.theage.com.au/environment/sustainability/south-australia-s-disappearingsprings-raise-questions-for-miner-bhp-20201117-p56f6m.html>.

${ }_{51} \quad$ See generally Moya Tomlinson, 'Ecological Water Requirements of Groundwater Systems: A Knowledge and Policy Review' (Waterlines Report Series No 68, National Water Commission, December 2011).

52 See generally Rebecca Nelson and Philippe Quevauviller, 'Groundwater Law' in Anthony J Jakeman et al (eds), Integrated Groundwater Management: Concepts, Approaches and Challenges (Springer Nature, 2016) 173. 
Australian national water reforms in the 2000s required statutory water plans to make provision for ecological water requirements, including as to groundwater. ${ }^{53}$ Federal and state governments have also funded substantial initiatives to identify and map GDEs across Australia. 54

Any GDE is directly threatened by groundwater withdrawals that, cumulatively, reduce their access to groundwater below ecologically relevant thresholds. For example, aquifer drawdown may reduce or stop the flow of springs that support desert wetlands, or lower water tables accessed by the roots of vegetation. .5 The impacts of multiple withdrawals may overlap, increasing the severity of impacts like water level declines in the overlapping zone. However, uncertainty about ecological thresholds for groundwater access is often high. ${ }^{56}$

Groundwater withdrawals may also threaten ecological restoration and ongoing conservation management practices. Conservation landholders may make substantial investments in restoring GDEs, for example releasing and safeguarding captive-bred endangered species into groundwater spring habitats. ${ }^{57}$ Groundwater wells may support the domestic needs of on-site conservation reserve managers. One might speculate that, in the future, landholders may even resort to pumping groundwater directly to support species and ecosystems that are not naturally groundwater dependent. For example, such an approach could help 'tide over' high-value species or ecosystems affected by drought or to protect species threatened by drying trends heralded by climate change. ${ }^{8}$ 'Artificially' using groundwater is already practised and legally recognised in some Australian and overseas jurisdictions. ${ }^{59}$ This may become

\section{Ibid $180-1$.}

54 See, for example, 'Groundwater Dependent Ecosystems Atlas', Bureau of Meteorology (Web Page) <http://www.bom.gov.au/water/groundwater/gde/>; Department of Science, Information Technology and Innovation (Qld), Queensland Groundwater Dependent Ecosystem Mapping Method: A Method for Providing Baseline Mapping of Groundwater Dependent Ecosystems in Queensland (Report, April 2015); Tomlinson (n 1).

55 Tomlinson (n 51) 39, 47 (in respect of vegetation); Angela H Arthington et al, 'Springs of the Great Artesian Basin: Oases of Life in Australia's Arid and Semi-Arid Interior' (2020) 126 Proceedings of the Royal Society of Queensland 1, 5.

56 Melissa M Rohde, Ray Froend and Jeanette Howard, 'A Global Synthesis of Managing Groundwater Dependent Ecosystems Under Sustainable Groundwater Policy' (2017) 55(3) Groundwater 293, 293, $295,298$.

57 Ellie Grounds, 'Captive-Bred Populations of Critically Endangered Red-Finned Blue-Eye Fish Released into Wild for First Time', $A B C$ News (online, 17 February 2021) <https://www.abc. net.au/news/2021-02-17/red-finned-blue-eye-fish-released-critically-endangered/13158496>.

58 See generally Gregor W Schuurman et al, Resist-Accept-Direct (RAD): A Frameworkfor the $21^{\text {st }}$ Century Natural Resource Manager (Report No 2213, 2020).

59 For example, national wildlife refuge managers in Montana, USA, are granted water rights for 'wildlife habitat maintenance and enhancement' purposes: 85-20-1301 Mont Code Ann $\S$ tit $85 \mathrm{ch}$ 20 pt 13 art III(F) (2021); Craig Clifton et al, 'Water and Climate Change: Impacts on Groundwater Resources and Adaptation Options' (Water Working Notes No 25, Water Sector Board of the Sustainable Development Network of the World Bank Group, June 2010) 58. See also n 254 below and accompanying text. For further discussion, see generally Rebecca Nelson, 'Water Rights for Groundwater Environments as an Enabling Condition for Adaptive Water Governance' (2022) Ecology and Society (forthcoming). 
more common as conservation managers consider how to respond to the potential effects of extreme heat or rainfall variability caused by climate change.

\section{Diagnosing LEgAL VULNERABILITIES AT THE INTERSECTION OF Private CONSERVATION LANDS, RESOURCES EXTRACTION, AND GROUNDWATER}

\section{A Analytical Framework}

\section{Relevant Laws and Approaches to Assessing Vulnerability}

Taking Queensland laws at the intersection of private conservation, mining and water, this Part addresses the question: How does Queensland law provide protection for, and redress in relation to, ecological assets on private conservation land that are at risk as a result of extractive activities that occur on and off the land? This analysis draws on three areas of law: first, laws that directly protect ecological assets by establishing conservation reserves and other place-based conservation measures (Part IIIB); ${ }^{60}$ second, laws that control environmental harms by providing for resources development authorisations and associated environmental impact assessment ('EIA') processes (Part IIIC); and third, water laws that protect the hydrological foundations of ecological assets - the water upon which they rely (Part IIID). While Commonwealth requirements also influence the practice of EIA, the focus here is state law, with reference made to existing work dealing with Commonwealth laws where appropriate. In any case, previous empirical research suggests that state laws influence a proponent's approach to complying with federal law. ${ }^{61}$

For each area of law, this article analyses both procedural and substantive protections. ${ }^{62}$ Procedural protections here refer to legal requirements to notify certain persons about the application for, or grant of, a relevant approval, giving that person an opportunity to comment, object or appeal. In the context of longrange groundwater impacts, effective procedural protections extend notification and objection provisions beyond the holder of the land proposed to be subject to a resources activity to other landholders who may be affected or to the public generally, ideally through direct notification of those who may be affected.

Substantive protections here refer to a requirement for a decision-maker to take into account environmental matters, including potential effects outside the

60

61 Rebecca Nelson, 'Big Time: An Empirical Analysis of Regulating the Cumulative Environmental Effects of Coal Seam Gas Extraction under Australian Federal Environmental Law' (2019) 36(5) Environmental and Planning Law Journal 531, 545-6, 548 ('Big Time').

62 Modifying and extending the framework used in Wawryk (n 16) 292-3. 
boundary of the resources tenure, when considering whether to approve a resources development and the conditions to apply to an approval. Considerations expected to be most effective specifically recognise the environmental importance of groundwater or GDEs, and the potential for multiple developments to cause cumulatively significant effects. Another substantive protection is a requirement to compensate a private landholder for damage caused by a resources development. This is a secondary protection, since it will often be practically difficult to reverse ecological damage to sensitive systems ${ }^{63}$ or even retrospectively attribute responsibility to individual human activities in the context of multiple groundwater-affecting activities and climate change effects. ${ }^{64}$

\section{Key Vulnerabilities: The Boundary Bias, the Infrastructure Bias, and the Singularity Bias}

This Part applies the framework advanced above, revealing the potential for environmental and development legislation to entrench serious vulnerabilities for private protected areas. These vulnerabilities stem from three outdated assumptions or structural biases entrenched in both the substantive and procedural aspects of the law. The first assumption is that the significant effects of mining are confined to areas within the boundary of the mine tenure and perhaps adjacent areas ('boundary bias'). This ignores the scientific fact that hydrological impacts may extend over long distances. Legally, this manifests in: (1) procedural provisions that restrict notification, objection and appeal rights to holders of the land subject to the resources activity, or adjacent to it; and (2) substantive provisions that only require environmental effects predicted to occur on the resources tenure (or adjacent lands) to be considered, even if they may, or are predicted to, extend further. ${ }^{65}$

The second assumption and structural bias is that protecting infrastructure assets and commercial assets suffices to neutralise the effects of mining on landholders ('infrastructure bias'). This ignores the fact that environmental policy increasingly relies on ecological assets located on private land formally dedicated to conservation, rather than built assets used for profit-making purposes. This bias manifests in provisions that restrict consideration or compensation in respect of effects to built infrastructure or narrow categories of ecological elements. ${ }^{66}$

63 Laurel Saito et al, 'Managing Groundwater to Ensure Ecosystem Function' (2021) 59(3) Groundwater 322, 323.

64 See generally Dapeng Feng et al, 'An Integrated Hydrological Modeling Approach for Detection and Attribution of Climatic and Human Impacts on Coastal Water Resources' (2018) 557 Journal of Hydrology 305, 305-6 (using a complex model to attribute changes in water resources to human activities and climate change).

65 See rows 1 and 2 in Figure 1 below: Part IIIE.

66 See row 3 in Figure 1 below: Part IIIE. 
The third is that the impacts of a proposed activity can be considered in isolation, without considering the significance of that activity in the light of the impacts of other activities on the same environment and the effects of climate change ('singularity bias'). ${ }^{67}$ This ignores the growth in resources developments, locked-in climate change effects, and the need to consider the cumulative effects of developments. ${ }^{68}$ This Part describes the legal sources of these three key vulnerabilities and explains that, while important legislative amendments have properly started to correct these biases in narrow statutory contexts in Queensland, further reform is required.

\section{B Protecting Ecological Assets: Place-Based Ecological Conservation and Private Conservation Land}

\section{Nature Refuges}

Queensland's most common private protected area is the nature refuge. ${ }^{69}$ Individual nature refuges are listed in regulations ${ }^{70}$ issued under the Nature Conservation Act 1992 (Qld) ('Nature Conservation Act') and administered by the Environment Minister..$^{71}$ A landholder (which is broadly defined) ${ }^{72}$ voluntarily agrees ${ }^{73}$ to manage a nature refuge under a conservation agreement to conserve their 'significant cultural and natural resources' 74 by undertaking (or refraining from) specified land management practices, potentially with State-provided financial or technical support. ${ }^{75} \mathrm{~A}$ conservation agreement binds its parties and successor landholders. ${ }^{76}$ Since the mechanism is based on consent, it does not

\footnotetext{
See row 4 in Figure 1 below: Part IIIE.

For a discussion of considering cumulative effects in groundwater law, see Rebecca Louise Nelson, 'Regulating Cumulative Impacts in Groundwater Systems: Global Lessons from the Australian Experience' in Cameron Holley and Darren Sinclair (eds), Reforming Water Law and Governance: From Stagnation to Innovation in Australia (Springer, 2018) 237.

The full suite of protected area types is outlined in Nature Conservation Act (n 33) s 14 .

Nature Conservation (Protected Areas) Regulation (n 26) sch 5. Thus, revocation requires a regulation: Nature Conservation Act (n 33) s 50. But note that a landholder may request to terminate a conservation agreement under Nature Conservation Act (n 33) s 47(2)(a)(i).

Currently the Minister for Environment and the Great Barrier Reef ('Environment Minister') and Department of Environment and Science: Governor in Council (Qld), Administrative Arrangements Order (No 2) (7 October 2021) 31-2 ('Administrative Arrangements Order').

The term 'landholder' is broadly defined to include 'a person having an interest in land': Nature Conservation Act (n 33) s 44(6). Accordingly, leasehold land as well as freehold land may be declared a nature refuge.

Note that a nature refuge may also be the subject of a compulsory declaration: Nature Conservation Act (n 33) s 49.

Nature Conservation Act (n 33) s 22(a). A conservation agreement for the refuge lists 'the significant cultural and natural resources and values of the nature refuge' and permits, restricts or requires to be conducted, certain activities and uses of the refuge land: Nature Conservation (Protected Areas) Regulation (n 26) s 8(1)(a)-(b).

Nature Conservation Act (n 33) s 45.

Ibid s 51(1).
} 
affect activities beyond the boundaries of the refuge land that may impact the refuge.

Even within nature refuge boundaries, there is no statutory prohibition on mining, nor any requirement for the Environment Minister's consent for mining, nor an automatic requirement for a form of EIA, as there is for some public protected areas. ${ }^{77}$ No legal mechanism under the Nature Conservation Act provides for considering the adverse effects on conservation land of activities that are undertaken off the refuge land either individually or cumulatively. This reflects the boundary bias by limiting protection for conservation objectives on refuge land to the refuge boundaries rather than the statute addressing external risks to the refuge acknowledged by other statutes or referring to that acknowledgement. ${ }^{78}$ Queensland's central nature conservation law leaves nature refuges completely vulnerable to resources activities both within and outside refuge boundaries.

\section{Strategic Environmental Areas}

In the context of increasing conflict between miners and landholders, the Regional Planning Interests Act 2014 (Qld) ('Regional Planning Interests Act')79 sought to 'provide the ability to manage the impacts of resource activities and regulated activities in areas of regional interest that contribute, or are likely to contribute, to Queensland's economic, social and environmental prosperity'. ${ }^{80}$ Though largely focused on agricultural land, ${ }^{81}$ the Regional Planning Interests Act also protects designated 'strategic environmental area[s]' 82 by requiring a 'regional interests development approval' to undertake a new resources activity in such an area. ${ }^{83}$ This mechanism can therefore be considered another form of 'placebased' protection for ecological assets. While strategic environmental areas currently cover few nature refuges, ${ }^{84}$ as discussed below, the regime likely offers Queensland's best place-based protection at the intersection of mining, conservation, and water. This highlights the relative attractiveness of strategic

\footnotetext{
Ibid ss 34(1), 53-5.

See discussion below in Parts IIIC, D.

Regional Planning Interests Act 2014 (Qld) ('Regional Planning Interests Act'). The Act is an amalgam of the former Wild Rivers Act 2005 (Qld) and the Strategic Cropping Land Act 2011 (Qld): Environmental Defenders Office (Qld), Review of the Regional Planning Interests Act 2014 (undated) 1, <https://d3n8a8pro7vhmx.cloudfront.net/lockthegate/pages/6385/attachments/original/1572 913356/190904_Brief_Report_on_the_RPI_Act_2014.pdf?1572913356> ('Review of the Regional Planning Interests Act').

8o $\quad$ Explanatory Notes, Regional Planning Interests Bill 2013 (Qld) 1.

81 Regional Planning Interests Act (n 79) ss 8, 10 ('priority agricultural area[s]' and 'strategic cropping area[s]', respectively).

Ibid s 11 .

Ibid s 19. Pre-existing resource activities are exempt from the scheme: s 24 .

The current spatial extent of both strategic environmental areas and nature refuges can be viewed interactively on the Queensland Globe: Queensland Government, Queensland Globe (Web Page, 2021) https://qldglobe.information.qld.gov.au/ (Add layers > Planning cadastre > Areas of regional interest $>$ Strategic Environmental Area and Environment > Nature refuge).
} 
environmental areas, and especially designated precincts within these areas, for expanding private conservation in the future.

Procedurally, protections for strategic environmental areas resist the boundary bias: notice and comment provisions for a regional interests development approval apply not only to the landholder 85 but also the broader public, ${ }^{86}$ though there is no requirement to directly notify potentially affected landholders outside the proposed approval site. The apparent strength of this provision is also undermined by the potential to grant an exemption to the public notification requirement, which effectively makes public notification discretionary. ${ }^{87}$ Public submissions must be considered in an approval decision, ${ }^{88}$ which any holder of affected land (even beyond the immediate landholders) may appeal. $^{89}$

Substantively, the strategic environmental area regime offers comparatively good (though not entirely secure) protections from mining within these areas. It also specifically recognises the ecological importance of groundwater and goes some way to displacing the boundary bias. Activities within 'designated precincts' must not 'compromise the preservation of the environmental attribute', 90 though outright prohibitions on mining are rare and the requirements of 'preservation' are unclear. ${ }^{91}$ Outside these precincts, but within the strategic environmental area, the process for a regional interests development approval involves considering whether a resource activity ${ }^{92}$ may contravene a prohibition on 'widespread or irreversible impact on an environmental attribute' of the area. 93 This may involve considering effects beyond the tenure area (though this is unclear), but does not clearly require considering cumulative effects (though 'widespread ... impact' seems to suggest this). Diverse hydrological features, such as aquifers, springs, waterholes, and GDEs, appear frequently among listed environmental attributes. ${ }^{4}$ Conversely, conditions applied to regional interests development approvals (including conditions with an environmental purpose) must not 'unreasonably' impose on an activity, 95 a term that is not defined in

\footnotetext{
Regional Planning Interests Act (n 79) s 35(1)(b).

Ibid ss 35, 37; Regional Planning Interests Regulation (Qld) r 13(2) (requiring publication in a newspaper at least once) ('Regional Planning Interests Regulation').

Ibid s 34(3). An exemption may be granted if the chief executive is 'satisfied there has been sufficient notification under another Act or law of the resource activity or regulated activity to the public', even though other Acts will not apply the same criteria for approval: Review of the Regional Planning Interests Act (n 79) 4.

Regional Planning Interests Act (n 79) s 49(1)(c).

Ibid ss 52(2)(c), 71 (definition of 'affected land owner'), 72, 73.

Regional Planning Interests Regulation s 14, sch 2 pt 5 item 15.

Ibid. Broader prohibitions apply only to the prescribed Cape York designated area: sch 2 item 15(2)(a). Precisely what is required to 'preserve an attribute' is unclear, so the strength of this formulation is uncertain: Review of the Regional Planning Interests Act (n 79) 4-5.

Regional Planning Interests Act (n 79) s 49(1)(b).

Regional Planning Interests Regulation (n 6) sch 2 pt 5 item 14.

Ibid ss 7(a)(iv), (b), 8(a)(ii), (e), 9(a)(iv), (d)(ii), (e), 10(e).

Regional Planning Interests Act (n 79) s 50(2).
} 
legislation, regulation or policy. Strategic environmental areas receive no explicit protection from effects caused by activities outside their boundaries. ${ }^{96}$ This regime would give consideration to important ecological attributes of nature refuges within a strategic environmental area that could be threatened by resources activities within that area, but not from resources activities outside the area. The Regional Planning Interests Act also does not require compensation in respect of damage to strategic environmental areas. More broadly, administration of the regime by the Minister for State Development, Infrastructure, Local Government and Planning97 appears poorly aligned with ecological goals.

\section{Controlling Development Impacts: Resources Tenures and Associated Environmental Approvals}

As distinct from directly protecting ecologically-valuable places, legislative frameworks for resources tenures and associated environmental approvals provide an alternative opportunity to protect these places from the effects of resources activities by constraining those activities. While the analysis here is restricted to systematically considering each of these regulatory regimes in general, it is important to note that they may interact and apply in complex, potentially ambiguous and controversial ways that are unique to individual projects. 98

\section{Resources Tenures}

The state grants resources tenures to permit exploration and commercial production of resources like petroleum, coal, gas, or metals, 99 which are owned by the Crown. ${ }^{100}$ Tenures may be granted on any land, ${ }^{101}$ other than a national park, conservation park, or special wildlife reserve, on which these activities are prohibited. ${ }^{102}$ No similar prohibition applies to nature refuges, and the

Ibid s 19(2): 'a person must not carry out ... a resource activity or regulated activity in an area of regional interest unless the person holds, or is acting under, a regional interests development approval for the activity' (emphasis added).

Administrative Arrangements Order (n 1 ) 3.

See, eg, the description as applied to a coal mine declared to be a significant project in Hancock Coal (n 14) [55]-[130].

Note that the focus here is relatively large-scale resource activities, excluding artisanal mining. Mineral development licences, which are issued to exploration permit holders and allow more intensive viability tests like drilling and seismic surveys, are here classified in the category of 'exploration'.

Mineral Resources Act 1989 (Qld) ss 6, 8 ('Mineral Resources Act'); Petroleum and Gas (Production and Safety) Act 2004 (Qld) s 26 ('Petroleum and Gas Act').

Mineral Resources Act (n 100) s 9(3).

Nature Conservation Act (n 79) S 27. Also note that the landholder's consent is required in relation to 'restricted land' near certain buildings and structures: Mineral and Energy Resources (Common Provisions) Act 2014 (Qld) ss 68 ('restricted land'), 70 ('Mineral and Energy Resources Act'). 
landholder's consent is not required - a position that both the legal ${ }^{103}$ and global conservation ${ }^{104}$ literatures consider deeply unsatisfactory. Both exploration and production may pose ecological risks. The apparently benign concept of 'exploration' 105 may involve significant disturbance, as with digging large test pits to mine over one hundred thousand tonnes of coal under a single exploration permit, in basins that may be covered by more than one hundred such permits. ${ }^{106}$

Separate resources tenure laws apply to approvals for exploring and producing gas and petroleum, and minerals, including coal (which, for simplicity, are here generically termed 'resources tenures'). ${ }^{107}$ These laws operate alongside the Environmental Protection Act 1994 (Qld) ('Environmental Protection Act'), ${ }^{108}$ which provides for assessing and controlling likely harms.

Procedural protections may theoretically arise at multiple stages in processes related to resources tenures through legal mechanisms that call for proponents or regulators to consult widely and, ideally, directly, with potentially affected landholders. The first occasion for this arises in calling for tenders for resources tenures. ${ }^{109}$ However, there is no legal requirement to consult, and in practice, consultation undertaken as a matter of policy may be tokenistic in respect of farmers and non-existent in respect of conservationists. ${ }^{110}$ No substantive requirement to consider environmental issues or incompatible land uses applies to releasing land for tenders. This is an important omission for which later environmental authorities cannot fully compensate, since in some respects, the horse has already bolted once land is released.

Procedural protections might next arise in notification and comment processes for an individual application for a resources tenure. These procedures are weak for mining and non-existent for petroleum and gas: direct notification requirements do not apply to petroleum authorisations ${ }^{111}$ or minerals exploration, ${ }^{112}$ but apply to 'affected persons' for mining leases. ${ }^{113}$ Reflecting a boundary bias, only owners of the subject land, adjoining land, or access land are

\footnotetext{
103 See, eg, Wawryk (n 16).

$104 \quad$ Adams and Moon (n 30) 117. See also above Section IIIB1.

105 Entitlements under an exploration permit are set out in Mineral Resources Act (n 100) s 129.

106 'Current Activity and Tenements: Resource Assessment for the Galilee Subregion', Bioregional Assessments (Web Page, 5 January 2018) < https://www.bioregionalassessments.gov.au/assessments/ 12-resource-assessment-galilee-subregion/122-current-activity-and-tenements $>$. Petroleum and Gas Act (n 101); Mineral Resources Act (n 101). Note that offshore petroleum regulation is beyond the scope of the current article.

108 See below 136 and accompanying text.

109 Petroleum and Gas Act (n 100) ss 35 (tenders for an authority to prospect), 127 (tenders for a petroleum lease); Mineral Resources Act ss 136C (exploration permit for coal), 317Z (tenders for a mining lease).

110 Queensland Audit Office, Managing Coal Seam Gas Activities (Report No 12, 2019-20) 11 ('Managing Coal Seam Gas Activities').

$111 \quad$ Petroleum and Gas Act (n 100) ch 2 pts 1-2.

${ }_{112}$ Mineral Resources Act (n 100) chs 4 (exploration permits), 5 (mineral development licences).

113 Ibid s 252A(1).
} 
considered 'affected', excluding others within the area of likely physical impact. ${ }^{114}$ Mining lease applications are also published in newspapers and posted online, ${ }^{115}$ with a basic search function. ${ }^{116}$ However, understanding potential off-site impacts of applications, particularly given the scientific complexity and potentially large areas of impact, ${ }^{117}$ puts a heavy ongoing burden on conservation landholders to keep abreast of applications that may affect them. Any 'entity' may object to the grant of a mining lease and trigger a hearing in the Land Court, assuming they discover the application and recognise that they may be affected. ${ }^{118}$

Despite having objectives to minimise land use conflict and encourage environmental responsibility alongside purposes to facilitate resources activities, ${ }^{119}$ and despite major resources tenures legally authorising interference with groundwater, ${ }^{120}$ resources tenure laws make scant mention of considering environmental issues and no mention of conflicts with ecological investments in private conservation land. These matters are largely left to EIA laws, ${ }^{121}$ despite the fact that resources tenure laws do deal with conflicts with more traditional forms of investment in private land. Where environment-related considerations do appear in resources tenure laws, there is no express requirement to consider cumulative effects and strong evidence of the infrastructure and boundary biases. No environmental provisions apply under resources tenure laws to approving minerals exploration ${ }^{122}$ or petroleum tenures. ${ }^{123}$ The internal departmental templates that apply to the latter mention environmental issues, ${ }^{124}$ but, in practice, these matters are given little weight in non-transparent decisionmaking processes. ${ }^{125}$ Environmental considerations that apply to other resources tenures are broad and vague, making no reference to conservation land. ${ }^{126}$ Resources tenure laws do not explicitly provide for imposing environmental

Ibid s 252A(1), (7). The applicant must also advertise the application in a local newspaper: s 252A(3). Entry onto land also requires notice: Mineral and Energy Resources Act (n 102) s 39.

Mineral Resources Act (n 100) s 252A(3); Business Queensland, 'Mining Lease Application Notices', Appling for a New Mineral or Coal Resource Authority (Web Page, 5 October 2021) <https://www.business.qld.gov.au/industries/mining-energy-water/resources/mineralscoal/authorities-permits/applying/mining-lease-application>.

Business Queensland, 'Public Searches For Resource Authorities', Business Queensland (Web Page, 10 November 2021) <https://www.business.qld.gov.au/industries/mining-energy-water/resources/ minerals-coal/online-services/searches $>$.

See above $\mathrm{n} 49$ and below $\mathrm{n} 8$ and accompanying text.

Mineral Resources Act (n 100) ss 260, 265 (in relation to a mining lease).

See, eg, Mineral Resources Act (n 100) ss 2(c), (d), (g).

Mineral Resources Act (n 100) ss 334ZP (in relation to mineral development licences and mining leases); Petroleum and Gas Act (n 100) s 185. As a result, grounds for objection to a relevant tenure are likely to include matters related to groundwater impacts. See further discussion in Part IIID2. See discussion in Part IIIC2.

Mineral Resources Act (n 100) ss 136 (minerals other than coal), 136K (permit after a tender process), $136 \mathrm{~S}$ (application, other than tender). Note narrow reference to the 'public interest' in relation to some coal exploration permits: s 136S(1)(b), (5).

Petroleum and Gas Act (n 100) ss 43 (criteria regarding authority to prospect for petroleum); 134 (criteria regarding petroleum lease).

Queensland Audit Office, Managing Coal Seam Gas Activities (n 110) 12.

Ibid 11-12.

Mineral Resources Act (n 100) ss 269(4)(j), 271(b). 
conditions on a tenure. ${ }^{127}$ The applicable land access code is affected by the infrastructure and boundary biases: it protects only infrastructure and introduced livestock, not native species or ecosystems or underlying water resources, and even its protections only apply on land affected by authorised activities. ${ }^{128}$ Similarly, both the infrastructure and boundary biases affect requirements to compensate landholders for damage. ${ }^{129}$ The compensation regime contemplates only damage ${ }^{130}$ to operational, rather than adjoining or more distant land, ${ }^{131}$ and does not clearly encompass damage to original or restored ecosystems within the central concepts of 'diminution of use' of the land, 'improvements', or 'loss or expense'. ${ }^{132}$ Using formal land valuations for compensation also disadvantages owners of nature refuges, ${ }^{133}$ since refuge declarations may reduce land value, ${ }^{134}$ and replacing ${ }^{135}$ unique, high conservation value land may be impossible.

\section{Assessing the Environmental Impacts of Resources Tenures}

Resources tenure laws lack meaningful procedural and substantive protections to benefit nature refuge lands, leaving EIA law as their major line of defence. Resources activities require an environmental authority under the Environmental Protection Act before a resources tenure can issue. ${ }^{136}$ Three types of authorities may

Mineral Resources Act (n 100) s 141 (exploration permit for minerals); s 231G (mineral development licences, though there is mention of conditions in the 'public interest': s 231G(2)); s 276 (mining leases, with analogous mention of the 'public interest': s 276(1A)); Petroleum and Gas Act (n 100) s 20 (petroleum titles). A minor exception is a condition that applies in relation to weeds: Mineral Resources Regulation 2013 (Qld) sch $1 \mathrm{cl}$ 2. See discussion of environmental authorities in Part IIIC2. Mineral Resources Act (n 100) s 141 (compliance with land access code is a condition of an exploration permit for coal); Department of Natural Resources and Mines (Qld), Land Access Code (September 2016) 7-9 <https://www.resources.qld.gov.au/_data/assets/pdf_file/0004/ 442633/land-access-code-2016.pdf>.

Note that separate regimes apply under the Mineral Resources Act (n 101) for mining leases, and under the Mineral and Energy Resources Act (n 102) for petroleum licences, mining exploration permits and mineral development licences, though the regimes are substantively similar in terms of the features discussed here.

Mineral and Energy Resources Act (n 102) ss 15A, 43.

Ibid s 81(1)(a); Mineral Resources Act (n 100) s 279(1)(a) (in relation to a mining lease).

Mineral Resources Act (n 100) ss 281(3)(ii), (iii), (v) (in relation to a mining lease); Mineral and Energy Resources Act (n 102) ss 81(4)(a)(ii), (iii), (v).

Department of Natural Resources, Mines and Energy (Qld), 'A Guide to Landholder Compensation for Mining Claims and Mining Leases', Department of Resources (Guide, September 2020) 7 <https: //www.resources.qld.gov.au/__data/assets/pdf_file/0007/1441447/landholders-compensationguide.pdf>.

34 'Claiming Conservation Covenant Concessions', Australian Taxation Office (Web Page, 13 January 2020) <https://www.ato.gov.au/non-profit/gifts-and-fundraising/in-detail/fundraising/claimingconservation-covenant-concessions/>.

Mineral Resources Act (n 100) s 281(4)(a).

Environmental Protection Act 1994 (Qld) ss 18 (meaning of 'environmentally relevant activity'), 107 (meaning of 'resource activity'), 110 (meaning of 'mining activity'), 111 (meaning of 'petroleum activity'), 426 (environmental authority required to carry out an 'environmentally relevant activity') ('Environmental Protection Act'); Petroleum and Gas Act (n 100) s 41(2)(b)(iii) (regarding authority to prospect for petroleum), 132(2)(b)(iv) (regarding petroleum leases); Mineral Resources Act (n 100) s 391A(3) (mining tenements); Queensland Audit Office, Managing Coal Seam Gas Activities (n 110) 12 . 
be issued, in increasing order of complexity and environmental scrutiny: (1) a standard authority with standard conditions for 'low-risk' sites; (2) an authority with a variation to standard conditions; and (3) a site-specific authority with sitespecific conditions. ${ }^{137}$ All petroleum leases require site-specific authorities, whereas most coal seam gas activities are approved under standard authorities involving 'limited' environmental assessment, ${ }^{138}$ and high reliance on the applicant's self-assessment of their ability to comply with standard conditions. ${ }^{139}$ The type of authority required for a mining lease will depend on the proposed activities..$^{140}$ From 2017-20, of 1076 applications for environmental authorities for resource activities (excluding coal seam gas, and amendment applications), $93 \%$ were for standard authorities, and only 3\% were for site-specific conditions. ${ }^{141}$ Though the standard authorities were likely for lower-risk activities, a clear question arises as to the potential for cumulative effects.

The assessment required to support an environmental authority depends on whether the project is a large 'coordinated project' subject to regulatory streamlining under the State Development and Public Works Organisation Act 1971 (Qld) ('State Development Act'),,142 or not (a 'regular project'). A regular project that requires a site-specific environmental authority may require an environmental impact statement ('EIS') to assess its likely impacts, ${ }^{143}$ whereas the EIA for a coordinated project occurs under the State Development Act. As a preliminary matter, it should be noted that the Environmental Protection Act references cumulative effects in defining 'environmental harm', stating that 'environmental harm may be caused by an activity ... whether the harm results from the activity alone or from the combined effects of the activity and other activities or factors'. ${ }^{144}$ Although this concept appears in the Act's offence provisions, ${ }^{145}$ it is not directly referenced in the provisions relating to the grant of environmental authorities. There appears little empirical evidence and no caselaw indicating the degree to which the concept of cumulative effects is operationalised in that context. The international literature on cumulative effects assessment gives one pause, suggesting that even where cumulative effects assessments are clearly

Queensland Audit Office, Managing Coal Seam Gas Activities (n 110) 13.

Ibid (but note that this publication does not differentiate between exploration tenures and petroleum leases; the 'coal seam gas activities' indicated may refer to exploration activities). Ibid 15.

Queensland Government, 'Environmental Authorities For Mining Projects', Community Involvement in Mining and Petroleum Lease Approvals (Web Page, 15 November 2021) <https://www.qld.gov.au/environment/pollution/management/impacts-approvals/impacts-mining>. Email from Department of Environment and Science to Lucas Volfneuk, 29 April 2021.

State Development and Public Works Organisation Act 1971 (Qld) s 27(2) ('State Development Act').

Environmental Protection Act (n 136) ss 143.

Ibid s 14(2)(b).

Ibid ss 319, 437, 438 and 493A. 
required, poor implementation may be the norm rather than the exception - the requirement viewed as a mere 'irritant to the completion' of EIA. ${ }^{146}$

\section{(a) Coordinated Projects}

Coordinated projects are those declared as such because they have significant environmental effects, significant infrastructure requirements, strategic state significance, or complex approval requirements. ${ }^{147}$ Recent examples include three large coal mine projects. ${ }^{148}$ The regime resists the boundary bias by identifying 'affected persons' in a way that appears to extend beyond landholders, ${ }^{149}$ assessing 'the significance of the relevant impacts', including long-term impacts, ${ }^{150}$ and identifying safeguards and mitigation measures. ${ }^{151}$

Procedural protections for coordinated projects vary. Comprehensive, multi-stage public notice and comment procedures apply to the more onerous EIS process, ${ }^{152}$ which informs the Coordinator-General in evaluating the environmental effects of the project and recommending approvals and desirable conditions $^{153}$ for the resources tenure ${ }^{154}$ and proposed environmental authority. ${ }^{155}$ In contrast, the 'streamlined'156 process for 'impact assessment reports' is simpler and may omit public notification altogether. ${ }^{157}$

An EIS for a coordinated project under the State Development Act (which is distinct from an EIS under the Environmental Protection Act, discussed below) is guided by formal, project-specific terms of reference, which may require cumulative impact analysis, ${ }^{158}$ and a generic policy guideline. While the project-

See Jenny Pope et al, 'Advancing the Theory and Practice of Impact Assessment: Setting the Research Agenda' (2013) 41 Environmental Impact Assessment Review 1, 5; A John Sinclair, Meinhard Doelle and Peter N Duinker, 'Looking Up, Down, and Sideways: Reconceiving Cumulative Effects Assessment as a Mindset' (2017) 62 Environmental Impact Assessment Review 183, 183. State Development Act (n 142) s 27(2).

${ }_{148}$ Coordinated project declarations are gazetted: ibid s 26(1). See, eg, Coordinator-General of Queensland, 'Significant Project Declaration: Alpha Coal Project' in Queensland, Queensland Government Gazette, No 60, 24 October 2008, 1085; China Stone Coal: Coordinator-General of Queensland, 'Declaration of a Significant Project' in Queensland, Queensland Government Gazette, No 53, 31 October 2012, 275; Olive Downs Coal Project: Coordinator-General of Queensland, 'Declaration of a Coordinated Project' in Queensland, Queensland Government Gazette, No 29, 17 February 2017, 237.

State Development and Public Works Organisation Regulation 2020 (Qld) sch $1 \mathrm{~s} 7$ item 3(i) ('an identification of affected persons, including a statement mentioning any communities that may be affected and describing the communities' views'). Ibid sch $1 \mathrm{~s} 7$ items 4(b), (d).

Ibid sch $1 \mathrm{~s} 7$ item 5 .

State Development Act (n 142) ss 29, 34D, 52 (notice of the requirement for assessment, draft terms of reference, draft statement).

Ibid ss 34D, 52.

Ibid ss 45, 46 (mining lease), 49B (petroleum lease).

Ibid s 47C. For a discussion of environmental authorities, see above $n 136$ and accompanying text. Explanatory Note, State Development and Public Works Organisation Amendment Regulation (No.2) 2014 (Qld) 2.

State Development Act (n 142) ss 34E-L.

${ }_{158}$ See, eg, Hancock Coal (n 14) [15]. 
specific terms of reference determine the required content of an EIS, the Act's broad definition of the 'environment' is notable. It appears to avoid the boundary and infrastructure biases by broadly including references to natural resources and biodiversity in a spatially unlimited way, and social, economic and cultural conditions related to the environment, perhaps allowing consideration of nature refuges as social-economic structures for conservation. ${ }^{159}$

Under the policy guideline, proponents should consider the scale of an impact by considering cumulative effects, among other things, ${ }^{160}$ averting the singularity bias at a basic level. Unfortunately, there is no regulatory or policy guidance on what constitutes adequate consideration of cumulative effects. This is a significant omission, given concerns about the rigour of cumulative effects assessment in Australia and internationally, ${ }^{161}$ and the fact that past experience in Queensland shows the clear potential for cumulative adverse effects on other landholders. Cumulative groundwater effects were a significant issue ${ }^{162}$ in litigation brought by landholders (including a nature refuge owner) against the proposed Alpha Coal Mine in the Galilee Basin, a declared 'significant project' under the State Development Act.163 In relation to the groundwater modelling undertaken for the potentially impacted off-tenure areas under the relevant EIS, there was 'insufficient hard data to have a sufficient level of confidence that groundwater impacts will be as predicted by the model ... [I]mpacts unforseen by the model may very well occur to the disadvantage of landholders' ${ }^{164}$ Moreover, the Coordinator-General's recommended groundwater monitoring network only included locations on mine tenure sites, rather than outside their boundaries, and the Court was not satisfied that future impacts on landholders would be picked up, anticipating 'a potential tragedy to those landholders' if impacts were undetected due to inadequate monitoring justified by 'groundwater modelling and evidence [that] is far from precise' ${ }^{165}$

Analogous disputes about cumulative effects have arisen in litigation brought by landholders against the proposed Kevin's Corner Mine, another

The full definition is as follows: 'environment includes: (a) ecosystems and their constituent parts, including people and communities; and (b) all natural and physical resources; and (c) the qualities and characteristics of locations, places and areas, however large or small, that contribute to their biological diversity and integrity, intrinsic or attributed scientific value or interest, amenity, harmony and sense of community; and (d) the social, economic, aesthetic and cultural conditions that affect, or are affected by, things mentioned in paragraphs (a) to (c)': State Development Act (n 142) sch 4 (definition of 'environment').

160 Department of State Development, Tourism and Innovation (Qld), Preparing an Environmental Impact Statement: Guideline for Proponents (Guidelines, October 2020) 4.

See, eg, Rebecca Nelson, 'Water Data and the Legitimacy Deficit: A Regulatory Review and Nationwide Survey of Challenges Considering Cumulative Environmental Effects of Coal and Coal Seam Gas Developments' (2019) 23(1) Australasian Journal of Water Resources 24; Sinclair et al (n 146); Pope et al (n 146); Nelson, 'Big Time' (n 61).

${ }_{162}$ Hancock Coal (n 14) [140]-[200], [337]-[364].

163 Ibid [25], [30].

164 Ibid [193].

165 Ibid [349]. 
declared significant project in the Galilee Basin. ${ }^{166}$ In that case, the court noted the lack of 'legislative[ly] endorse[d]' guidance on cumulative impact assessment. ${ }^{167}$ Landholders noted that the bore survey undertaken by the proponent had not identified their bores, and model outputs had failed to show areas likely to be affected by groundwater drawdown, despite the fact that other nearby mines were predicted to impact bores located up to 30 kilometres away. ${ }^{168}$ These cases suggest that the framework for analysing the cumulative effects of resources developments would benefit from more strongly resisting the singularity bias through clear guidance on cumulative impact analysis, beyond a mere policy mention. The framework would also benefit from specific attention to the position of private conservation landholders, which currently may be overlooked in practice.

\section{(b) Regular EIA}

A regular resources project that requires a site-specific authority generally requires an EIS under the Environmental Protection Act ${ }^{169}$ - recalling that these account for only $3 \%$ of projects and represent a 'best case scenario' in terms of the robustness of environmental controls. The relevant provisions use the same broad definition of the environment as applies to coordinated projects. ${ }^{170}$ When deciding whether an EIS is required, the department must consider a legally binding list of standard criteria, which includes 'all submissions', but does not expressly mention cumulative effects. ${ }^{171}$ However, current policy requires consideration of 'the spatial and chronological extent of potential cumulative impacts', noting that a 'project [that] is likely to contribute substantially to cumulative impacts' may require an EIS. ${ }^{172}$ It adds that '[u]nacceptable cumulative impacts may occur when the environmental impacts of a project are added to existing environmental impacts contributed to by other activities over space and time, [for example,] impacts to the local airshed, a regional water catchment, or the environmental values of aquifers. ${ }^{173}$ Information noted as relevant to a determination about cumulative impacts includes various kinds of

\footnotetext{
166 See generally Hancock Galilee Pty Ltd v Currie [2017] QLC 35.

167 Ibid [90].

168 Ibid [91].

169 Exceptions apply to coordinated projects: Environmental Protection Act (n 136) ss 125(3), (6) (in relation to mining leases), 126(3) (in relation to coal seam gas activities) and projects subject to joint state-federal assessment: Environmental Protection Regulation 2019 (Qld) ss 4, 6, 7.

$170 \quad$ Environmental Protection Act (n 136) s 8, sch 4 (definition of 'environment').

${ }_{171}$ Ibid sch 4 (definition of 'standard criteria'); Department of Environment and Science (Qld), Guideline: Criteria for Environmental Impact Statements for Resource Projects under the Environmental Protection Act 1994 (Guideline ESR/2016/2167, 2016) 3, 6 (app B). Note that cumulative effects may implicitly fall within one of the listed criteria, eg, precautionary principle, intergenerational equity, or conservation of biological diversity and ecological integrity.

172 Ibid 3.

173 Ibid 3-4.
} 
environmental plans and assessments and 'matters of national and state environmental significance' ${ }^{174}$ but conservation land is not expressly mentioned.

Procedural protections are limited compared to coordinated projects: the boundary bias emerges in a limited way in that only interest-holders in the operational and adjoining lands are considered 'affected persons' 175 who receive direct notifications ${ }^{176}$ in addition to the regular public notice requirements. ${ }^{177}$ Any person may make a submission about the EIS, ${ }^{178}$ which must be published online, though only for a limited period of time. ${ }^{179}$ Submissions inform the Department's recommendations in an EIS assessment report about the suitability of the project and appropriate conditions. ${ }^{180}$ There is a further public submissions stage in relation to the grant of an environmental authority, but generally only if there have been significant changes in environmental risks since the EIS was notified. ${ }^{181}$ Any submitter may object to the grant of an environmental authority for a mining lease or other resource before the Land Court. ${ }^{182}$ Although this alleviates the boundary bias in a basic way, as noted in relation to mining lease applications, this burdens individual landholders with the need to keep abreast of applications that may affect them, though they are more distant from the relevant site. ${ }^{183}$

Substantively, an EIS assesses a project's likely impact on 'environmental values' ${ }^{184}$ defined in formal policies, ${ }^{185}$ under project-specific terms of reference guided by a policy template ${ }^{186}$ that is much more detailed than that available for coordinated projects. The terms of reference template explicitly refers to off-site conservation properties and groundwater: it requires the proponent to ' $d$ d]escribe and illustrate the precise location of the proposed project in relation to any designated and protected areas and waterbodies', to show aquifers that could be influenced by the proposed project's activities, ${ }^{187}$ and to describe proposed 'take of surface and groundwater (both direct and indirect)'. ${ }^{188}$ However, documented state-wide and basin-specific ${ }^{189}$ environmental values for water (including

Ibid 4 .

Environmental Protection Act (n 136) ss 38 (definition of 'affected person'), 41(3)(d) (note this also includes local government).

Ibid ss 43(3)(a) (in relation to draft terms of reference), 51(2)(a)(i) (in relation to the EIS).

Ibid 551 (in relation to the EIS).

Ibid $\mathrm{s} 54$.

Ibid s 51(4).

Ibid ss 58, 59 .

Ibid ss 150, 160 (an 'entity' may make a submission).

Ibid ss 182, 183, sch 2 pt 1 div 3.

See above $\mathrm{n} 117$ and accompanying text.

Environmental Protection Act (n 136) ss 4, 9 ('environmental value'), 125(1)(l)(i).

Ibid ss $26,27(2)(d)$.

Department of Environmental and Science (Qld), Draft Terms of Reference for an Environmental Impact Statement under the Environmental Protection Act 1994 (ESR/2017/4038, 2017) $<$ https://environment.des.qld.gov.au/ data/assets/word_doc/0024/208077/eis-fm-generictor.docx>.

Ibid 5-6.

Ibid 7.

Environmental Protection (Water and Wetland Biodiversity) Policy 2019 (Qld) sch 1. 
groundwater and associated 'aquatic ecosystems') ${ }^{190}$ do not quantify relevant protections, and appear to focus narrowly on water quality despite including broader management goals. ${ }^{191}$ Coal seam gas and coal projects, which involve 'underground water rights', benefit from additional information requirements about water. ${ }^{192}$ They require a description of how aquifer decline may affect environmental values and strategies for avoiding, mitigating or managing these impacts. ${ }^{193}$

Policy requires that the EIS consider cumulative effects in determining the scale of the impact of the project, including cumulative effects on water resources. ${ }^{194}$ However, there are no guidelines to describe what is required of a cumulative effects assessment. Policy also expressly requires the consideration of GDEs and the 'integrity of landscapes and places (including wilderness, areas of high conservation value and similar places, connectivity of habitats and ecosystems)', ${ }^{195}$ though there is no direct link to cumulative impact concerns. These factors resist the infrastructure and singularity biases, but there is no mention of private conservation land. This omission appears incongruous given that other important land uses are specifically called out as requiring attention in the EIS, including impacts on agricultural activities, recreational activities, and native title and cultural heritage, ${ }^{196}$ and given that 'designated and protected areas' are called out in the terms of reference guidelines. ${ }^{197}$

An EIS can result in conditions on an environmental authority for preventing or rehabilitating environmental harm, including by using offsets, and restraining the exercise of underground water rights. ${ }^{198}$ Such conditions seem unlikely to reliably restrain long-range harms to private conservation land without a requirement to consider this matter. As a matter of policy, activities in nature refuges are considered in setting conditions of standard environmental authorities for mining leases and 'where necessary and desirable' for site-specific environmental authorities, but this is not required if activities occur within a buffer zone around the refuge, as applies to public conservation land. ${ }^{199}$ Unlike

Ibid sch 2: definitions of 'aquatic ecosystem', 'groundwater' and 'waters'.

See, eg, Department of Environment and Science (Qld), Queensland Murray-Darling and Bulloo River Basins: Groundwater Environmental Values and Water Quality Objectives (Policy Document, October 2020) 32 (setting a management goal to 'maintain or improve water-dependent ecosystems of the Murray-Darling Basin').

Environmental Protection Act (n 136) ss 126, 127. See also below n 231 and accompanying text.

Environmental Protection Act (n 136) ss 126, 126A.

Department of Environment and Science (Qld), Guideline: The Environmental Impact Statement Process for Resource Projects under the Environmental Protection Act 1994 (2019) 14, 29.

Ibid 35 .

Ibid 34, 37.

See above $\mathrm{n} 187$ and accompanying text.

Environmental Protection Act (n 136) s 207.

Department of Environment and Heritage Protection (Qld), Eligibility Criteria and Standard Conditions for Mining Lease Activities: Version 2 (ESR/2016/2241,2016) 1, 7 (condition A13), 31-2 (app 3) (nature refuges are 'category $C$ environmentally sensitive areas' requiring consultation with the Environment Department). 
public protected areas and special wildlife reserves, ${ }^{200}$ no offsets are required to counterbalance harms to nature refuges ${ }^{201}$ unless they meet certain narrow requirements. ${ }^{202}$ While the language of the Act appears broad enough to encompass effects that are caused by actions off-site, policy guidance focuses on direct impacts, such as vegetation clearing undertaken in the course of the resources activity. ${ }^{203}$

In summary, the spatially limited conception of 'affected persons' - the boundary bias - reduces the chance that nature refuge owners will find out about an application, the scope for investigation does not clearly address long-range risks to refuges, and there are no quantified levels of protection, though there is consideration of cumulative effects on water resources and ecological connectivity. These weaknesses in the regime that shoulders the greatest share of the burden of protecting the environment from the adverse effects of resources activities are plainly inconsistent with the state's desire to encourage private conservation, leaving these investments in conservation vulnerable to damage.

\section{Protecting Ecological Foundations: Water Law and Groundwater-Dependent Ecosystems}

Similar to the bifurcation in EIA between coordinated and regular projects, Queensland water law applies different water rights arrangements to resources projects depending on whether they fall into a general category subject to regular water entitlement and planning frameworks, as do irrigation and other commercial activities, or the special category of activities that benefit from 'underground water rights' and guaranteed legal access to water under rights that are not available to other water users. This Part reviews the general case first, before analysing the special case of underground water rights.

Environmental Offsets Act 2014 (Qld) s 8(5) (excepting nature refuges from the provision that refers generally to protected areas) ('Environmental Offsets Act'); Nature Conservation Act (n 33) s 14. Note policy suggests the contrary: Department of Environment and Heritage Protection (Qld), Queensland Environmental Offsets Policy: Significant Residual Impact Guideline (Policy Guideline, 2014) 14 (stating that nature refuges are included within the concept of protected areas that may suffer from a significant residual impact and require an offset) ('Queensland Environmental Offsets Policy').

Resources activities are prescribed activities: Environmental Offsets Regulation 2014 (Qld) sch $1 \mathrm{cl}$ 1; sch $2 \mathrm{cl} 7$ ('Environmental Offsets Regulation'). This constitutes a 'significant residual impact': Environmental Offsets Act (n 200) s 8(2).

Environmental Offsets Regulation (n 201) sch 2 cls 2 (endangered regional ecosystems, of concern regional ecosystems, essential habitat, etc); 3 (certain remnant vegetation in connectivity areas); 4 (high ecological value waters); 5 (designated precincts in strategic environmental areas); 6 (protected wildlife habitat).

203 See, eg, Queensland Environmental Offsets Policy: Significant Residual Impact Guideline (n 200) 5 (in relation to regulated vegetation). Note that other sections of this policy guideline are not phrased in a way that is clearly restricted to direct impacts: see 10 (in relation to wetlands and watercourses), 11 (in relation to protected wildlife habitat). 


\section{General Water Law}

Over most of Queensland, regulatory water plans require a person to apply for a water licence to take surface water or groundwater. ${ }^{204}$ These plans are intended to ensure the 'sustainable management of Queensland's water', taking into account principles like providing for broad community involvement, the precautionary principle and the principle of intergenerational equity. ${ }^{205}$

Procedurally, an application for a water licence is publicly notified (though no direct notifications of potentially affected landholders are expressly required by statute) and any entity may make a submission, ${ }^{206}$ averting the boundary bias at a basic level. Entities that have made a submission may appeal a decision. ${ }^{207} \mathrm{~A}$ decision on a water licence must also be consistent with the relevant water plan. ${ }^{208}$ That makes these plans an important way to control aggregate withdrawals of water that they cover (though without an express requirement to consider cumulative impacts at the ecosystem level), and potentially a powerful way to recognise impacts on the ecological assets protected by private conservation lands. However, water plans do not control the issue of temporary water permits used for resources exploration and other temporary purposes, ${ }^{209}$ which separately require consideration of general criteria such as 'impacts on natural ecosystems' and 'the public interest'. ${ }^{210}$

A plan must state desired economic, social, cultural and environmental outcomes and arrangements for providing water for the environment, ${ }^{211}$ may include criteria for deciding whether to grant a water licence, and provides for a water management protocol, ${ }^{212}$ which implements the plan and sets out water sharing rules. ${ }^{213}$ Procedurally, there are comparatively few opportunities for public involvement in Queensland water plans compared to arrangements in some other states: ${ }^{214}$ they are prepared by the Minister rather than a stakeholder committee; the public may only make written submissions; ${ }^{215}$ and consultation is not mandatory before a full draft is available. ${ }^{216}$ Water management protocols are even less transparent, requiring only 'adequate consultation with persons

204 Water Act 2000 (Qld) ss 101(1)(c), 808 ('Water Act'). Plans now commonly apply across Queensland: Queensland Government, Queensland Globe (Web Page) <https://qldglobe.information. qld.gov.au/qldglobe/public/water-plan-areas-1>.

Water Act (n 204) ss 2(2) (defining 'sustainable management' as incorporating the principles of ecologically sustainable development), 7 (meaning of principles of ecologically sustainable development), 37 (linking water plans with sustainable management).

Ibid s 112 .

Ibid ss 114(7), 851(1) ('interested persons'), 862 (internal review), 877 (external review).

Ibid ss 114, 129(1).

Ibid 5137.

Ibid s 138(a)-(e).

Ibid ss 43(1)(b), (d).

Ibid ss 43(2)(h), (1).

Ibid ss 67,68 .

Alex Gardner et al, Water Resources Law (LexisNexis Butterworths, $2^{\text {nd }}$ ed, 2018) 327-34.

Water Act (n 204) s 46.

Ibid ss 42, 44(1), 46. 
affected by the protocol' ${ }^{217}$ There are no minimum environmental protections to be included in water plans in general, unlike under the federal requirements for an 'environmentally sustainable level of take' of water in the Murray-Darling Basin, including the portion of the Basin in Queensland. ${ }^{218}$

Outside water plans, substantive protection for nature refuges may theoretically arise under a requirement for ecological impacts to be considered in deciding whether to grant or refuse a licence. ${ }^{219}$ They may also arise through conditions requiring the licensee to provide alternative water supplies to a person who is authorised to take water, and who would be affected by the grant of a licence. ${ }^{220}$ The provision does not contemplate 'making good' effects on such a person where the water use is in situ and not directly 'taken', though perhaps there is potential to interpret it this way. This provides some potential (albeit untested) for nature refuge owners who are able to obtain a groundwater licence for in situ environmental water use - or even for water actively withdrawn to create refugia or otherwise mitigate climate change effects - to object to the grant of a water licence for resources extraction purposes and argue for alternative supplies to be provided. Although these provisions provide theoretical protection against the infrastructure bias, none makes express reference to impacts on the ecological assets of private conservation landholders.

\section{Special Arrangements for Resources Activities}

Whereas water licences and permits control the volumes of water used by the holder, special 'underground water rights' apply to important, but not all, ${ }^{221}$ resources extraction activities. These rights allow unlimited groundwater withdrawal as a by-product of the resources extraction activity ('associated water'). ${ }^{222}$ This includes dewatering coal seams to release coal seam gas, dewatering a coal mine to allow pit operations, and evaporation of water from a mining pit. ${ }^{223}$ Removing these uses from regular water entitlement frameworks arguably fundamentally 'abandons' the nationally agreed preference that water

\footnotetext{
217 Ibid s 68(1), (2)(c).

${ }_{218}$ Rebecca Nelson, 'Breaking Backs and Boiling Frogs: Warnings from a Dialogue between Federal Water Law and Environmental Law' (2019) 42(4) University of New South Wales Law Journal 1179, 1208-9, quoting Water Act 2007 (Cth) s 4(1) (definition of 'environmentally sustainable level of take').

$219 \quad$ Water Act (n 204) s $113(\mathrm{e})$.

$220 \quad$ Ibid s $118(2)(\mathrm{b})$.

221 See, eg, withdrawal for direct use in processing (termed 'non-associated water'): 'Water Reporting for Coal and Mineral Activities' Business Queensland (Web Page) <https://www. business.qld.gov.au/industries/mining-energy-water/resources/minerals-coal/reportsnotices/water-reporting $>$.

222 Petroleum and Gas Act (n 100) s 185; Mineral Resources Act (n 100) s 334ZP (implicitly in the latter case). Note that transitional provisions requiring a water licence apply in relation to projects already being actively considered before 2014: Mineral Resources Act (n 100) s 839.

223 Mineral Resources Act (n 100) s 334ZP(1) (introduced by the Water Reform and Other Legislation Amendment Act 2014 (Qld) s 11).
} 
plans should manage the aggregate effects of all water uses. ${ }^{224}$ It also reduces procedural protections for affected landholders - underground water rights arise as an incident of the mining activity and there is no public consultation process as for water licences. ${ }^{225}$ This 'light touch' approach to water rights was justified as being an 'offset' against the increased regulatory burden of the special arrangements for resources authority holders in cumulative management areas, described below. ${ }^{226}$

Nature refuges have limited protections under these special arrangements. Resource tenure holders must measure and report volumes taken ${ }^{227}$ and comply with the two major limbs of their 'underground water obligations':228 first, monitoring impacts on aquifers and springs; and second, 'making good' waterrelated impacts on landholders' bores. ${ }^{229}$ Obligations to prepare 'underground water impact reports' apply to individual tenure holders or to the Queensland Office of Groundwater Impact Assessment in declared 'cumulative management areas' affected by multiple resources tenures. ${ }^{230}$ This obligation, and other related obligations, ultimately fail to protect private conservation lands.

First, and positively, the 'underground water impact report', ${ }^{231}$ which assesses resources-related impacts and strategies and responsibilities for managing them, is subject to a public submissions process before it is finally approved. ${ }^{232}$ The report must include a long list of environmental matters, including affected aquifers, water level trends, areas predicted to decline more than threshold values over different time periods, a water monitoring strategy, and a spring impact management strategy. ${ }^{233}$ However, most information items are qualified by the requirement to demonstrate a causal link between an impact and 'the exercise of underground water rights'. Demonstrating this link requires removing the influence of other water-taking activities, like agriculture, as well as the background effects of climate variability. This is both technically complex $^{234}$ and conflicts with tenets of cumulative effects assessment, which are

\footnotetext{
224 Gardner et al (n 214) [27.22].

225 Note, however, the potential to object in relation to water concerns under resources laws: see above nn 111-118, 120 and accompanying text, and under EIA laws: see above nn 152-7 and accompanying text in relation to coordinated projects and nn 1755-83 in relation to 'regular' EIA).

226 Queensland, Parliamentary Debates, Legislative Assembly, 11 September 2014, 3259 (AP Cripps).

227 Mineral Resources Act (n 100) s 334ZP(5).

228 Ibid s 334ZP(2)(b); Petroleum and Gas Act (n 100) s 185(2)(b).

229 Water Act (n 204) s 361(2)(a)(i).

230 Ibid ss 365,370 .

$231 \quad$ Ibid s 370.

232 Ibid ss $381-86$.

233 Ibid ss 376-9. Note that some of these elements are also required for corresponding environmental authorities: Environmental Protection Act ss 126, 126A.

234 Matthew J Knowling, Adrian D Werner and Daan Herckenrath, 'Quantifying Climate and Pumping Contributions to Aquifer Depletion Using a Highly Parameterised Groundwater Model: Uley South Basin (South Australia)' (2015) 523 Journal of Hydrology 515, 515-16. See generally Feng et al (n 64).
} 
accepted globally and in Australia, ${ }^{235}$ and which are premised on considering and responding to the aggregate effects of all actions that impact the same environmental value. ${ }^{236}$ In terms of ecological impacts, the water monitoring and spring impact management strategies focus narrowly on springs rather than the more comprehensive range of GDEs considered in other contexts, including watercourse-related GDEs and terrestrial vegetation. ${ }^{237}$ There is no mandate to prevent or mitigate impacts to springs, ${ }^{238}$ and even the mandatory components of underground water impact reports do not bind resources tenure holders if they have 'a reasonable excuse'. ${ }^{239}$ More generally, the provisions for these obligations are curiously unmoored from the principles of ecologically sustainable development, including intergenerational equity, that apply to the water plan provisions. ${ }^{240}$

The second limb of a tenure holder's underground water obligations is to assess and 'make good' the impacts of the exercise of underground water rights on a bore ${ }^{241}$ by providing 'monetary or non-monetary compensation' or appropriate substitute water. ${ }^{242}$ The great detail of this framework - spread over 63 provisions - makes the omission of any mandate to 'make good' ecological damage all the more striking, and continues the infrastructure bias evident in compensation arrangements under resources tenure laws. The significant uncertainty that often surrounds relevant predictions of impacts, which may not prevent approvals, and the feasibility of compensating for decades- or centurieslong impacts, are also problematic. ${ }^{243}$

Tom Kaveney, Ailsa Kerswell and Andrew Buick, Cumulative Environmental Impact Assessment Industry Guide: Adaptive Strategies (Industry Guide, July 2015) 32 (stating that a 'major consideration for selecting these other actions is whether the action causes similar effects on the same environmental values/sensitive receptors as the project under assessment' (emphasis added)); Nelson (n 218) 1197-8 (meaning of 'other developments' in the definitions of 'coal seam gas development' and 'large coal mining development' under s 528 of the Environment Protection and Biodiversity Conservation Act 1999 (Cth)). F Chris Jones, 'Cumulative Effects Assessment: Theoretical Underpinnings and Big Problems' (2016) 24(2) Environmental Reviews 187, 191.

See above $\mathrm{n} 94$ and accompanying text.

Water Act (n 204) s 379(1)(d).

Ibid s 390.

Cf ibid ss 2(1)(a)(i), 37 (sustainable management in the context of water planning) and ss 2(1)(c) 361 (purpose of ch 3, which only mentions 'management of impacts'). See also Part IIID1 above.

Water Act (n 204) ch 3 pt 5.

Ibid 5421.

See, eg, Matthew J Currell et al, 'Problems with the Application of Hydrogeological Science to Regulation of Australian Mining Projects: Carmichael Mine and Doongmabulla Springs' (2017) 548 Journal of Hydrology 674. 


\section{E Summary of Legal Vulnerabilities and Current Good Practice in Queensland}

A complex assemblage of interacting areas of law and legal mechanisms regulates the potential for resources activities to damage private conservation lands beyond the boundary of the resources tenure. Procedurally and substantively, these regimes often leave private conservation lands vulnerable to ecological damage from resources activities through an assumption that a resources activity may damage only lands covered by, or adjacent to, a resources authority (boundary bias), a bias towards considering and protecting built infrastructure and commercial assets rather than ecological assets (infrastructure bias), and a bias towards considering the effects of individual developments in isolation, when they may have collectively significant effects (singularity bias). This Part summarises these biases, noting positive elements, before Part IV makes recommendations for strengthening protections for private conservation land.

The structural biases analysed here leave private nature conservation lands vulnerable to cumulative ecological damage from resources activities. They also reflect larger problems in insufficiently integrating legislative regimes across place-based protection mechanisms, development controls and natural resources planning laws. Consciously considering ecosystems as well as infrastructure in approvals processes (resisting the infrastructure bias) is laudable, but ineffective to address the harms in focus here if these considerations stop at the tenure boundaries (substantive boundary bias). Equally, legal directions to consider impacts beyond the resources tenure boundaries (resisting the substantive boundary bias) are meritorious, but may not amount to anything if conservation landholders are not notified about a resources proposal and cannot comment on the impacts of the proposal on their ecological assets or appeal a decision (procedural boundary bias). Similarly, legal directions to consider impacts beyond the resources tenure boundaries will offer limited benefits to conservation landholders if consideration only extends to impacts on infrastructure, not ecological assets (infrastructure bias). Even if a legal mechanism contains good notification and appeal provisions and considers impacts beyond the tenure boundaries, including in relation to ecosystems, protections will necessarily be inadequate if there is no provision for considering the cumulative effects of a proposed activity together with the effects of other human activities (singularity bias). Anything less under-estimates the true 'real world' environmental effect of resources proposals.

Even if all these requirements are fulfilled, one can only speak of a 'chance' of protection for nature conservation lands in which the state encourages private investment. Assuming relevant ecological information is available, a decisionmaker may take these matters into account, but approve a project on economic development or other grounds. Accordingly, removing these biases offers a bare 
minimum approach - just considering private conservation lands in ways that are consistent with Queensland's environmental reliance on them. In other words, even a relatively favourable assessment of the performance of a legal mechanism may not necessarily offer optimal protection for nature refuges, despite better resisting the relevant bias than in other cases. For example, the strategic environmental area regime resists the infrastructure bias since it explicitly requires consideration of ecological assets, but this is undermined by only prohibiting harm to the extent that this would not 'unreasonably' impose on a resources activity. Equally, an EIS that informs the grant of a site-specific environmental authority benefits from taking a broad ecological scope (that is, apparently low infrastructure bias in matters considered), but no offsets are required to counterbalance damage that this EIS predicts will occur (high infrastructure bias in matters protected).

In the absence of firm mandatory protections, matters considered may not ultimately be protected. In relation to the procedural issue of notification and appeal rights, even though a wide range of stakeholders may comment on or object to the approval of a permit, licence or plan, these comments may not sway the relevant administrator. Indeed, administrative arrangements show clear potential for decision-makers to have conflicting objectives that may limit their inclination to give weight to environmental objections. The Minister responsible for regional development is also responsible for administering the ecological protections under the water licensing, planning and underground water rights regimes, ${ }^{244}$ which in theory could constrain industrial aspects of regional development. The Minister responsible for state development and infrastructure is also responsible for the ecological protections under strategic environmental areas that in theory could constrain construction of infrastructure. The Coordinator-General responsible for significant major projects may state conditions for environmental authorities, and other conditions of the Environment Minister or Land Court may not be inconsistent with these. ${ }^{245}$

Figure 1 summarises how different individual elements of these legal regimes manifest the boundary, infrastructure and singularity biases using 'traffic light' matrix diagrams for legal mechanisms within three areas of law resources development, place-based nature conservation, and water. Analyses are presented using a separate matrix diagram for each of multiple legal mechanisms discussed within each area of law (for example, nature refuges under the Nature Conservation Act 1992 (Qld) ('Nature Conservation Act') and strategic environmental areas under the Regional Planning Interests Act). The matrix diagrams synthesise performance in terms of the boundary bias (substantive and procedural), infrastructure bias and singularity bias. Performance is classified as poor, moderate or good based on the definitions set out in the key. Where a legal

Administrative Arrangements Order (n 71) 25.

State Development Act (n 142) s 47C; Environmental Protection Act (n 136) s 205(4). 
regime provides for multiple processes, each regime is described using the 'best case scenario' of the most rigorous process, even where this is relatively uncommon (for example, a site-specific environmental authority rather than a standard authority or an authority with a variation to standard conditions under the Environmental Protection Act).246

Figure 1 is necessarily general and intended to capture the main findings of the article in relation to overall regulatory approaches (discussed in subsections 1 to 4 below), rather than how these findings would apply in the case of a specific resource development. That approach aligns with the focus of this article on the cumulative threats of multiple, and sometimes numerous, resources activities to private conservation lands. However, for completeness, it should be noted that in the case of a single resources development, in some cases, a weakness (bias) in one legal mechanism may be corrected by a stronger approach (resistance to bias) in another. For example, a public notice requirement under EIA law may alert a nature refuge owner to a nearby resources proposal even where resources tenure laws do not require the applicant for the tenure to give general public notice of the application. In other cases, weaknesses will run through multiple legal mechanisms that apply to a specific project, or ways of protecting key ecosystems, and leave key ecological assets on nature refuges fundamentally unprotected. This cumulative vulnerability is particularly evident for groundwater-dependent vegetation on nature refuges: these ecosystems are ignored by substantive protections under the land access code and compensation regimes that apply to resource tenure holders, and ignored by both information collection provisions and protections against damage in the context of underground water rights.

Given the complexity of the arrangements described here, visualising these biases across areas of law and legal mechanisms assists in making some general observations about the extent to which important legal mechanisms relevant to protecting nature conservation lands from resources activities evidence the boundary, infrastructure and singularity biases. It also assists in identifying legal mechanisms that perform well in relation to each area of structural bias - good practices that could be extended to help remedy vulnerabilities for conservation lands. General observations are presented for each bias in turn below. 


\section{Figure 1: Dimensions of Structural Legal Bias Affecting Protections for Private Conservation Lands from Cumulative Resources Threats, by Area of Law and Legal Mechanism}

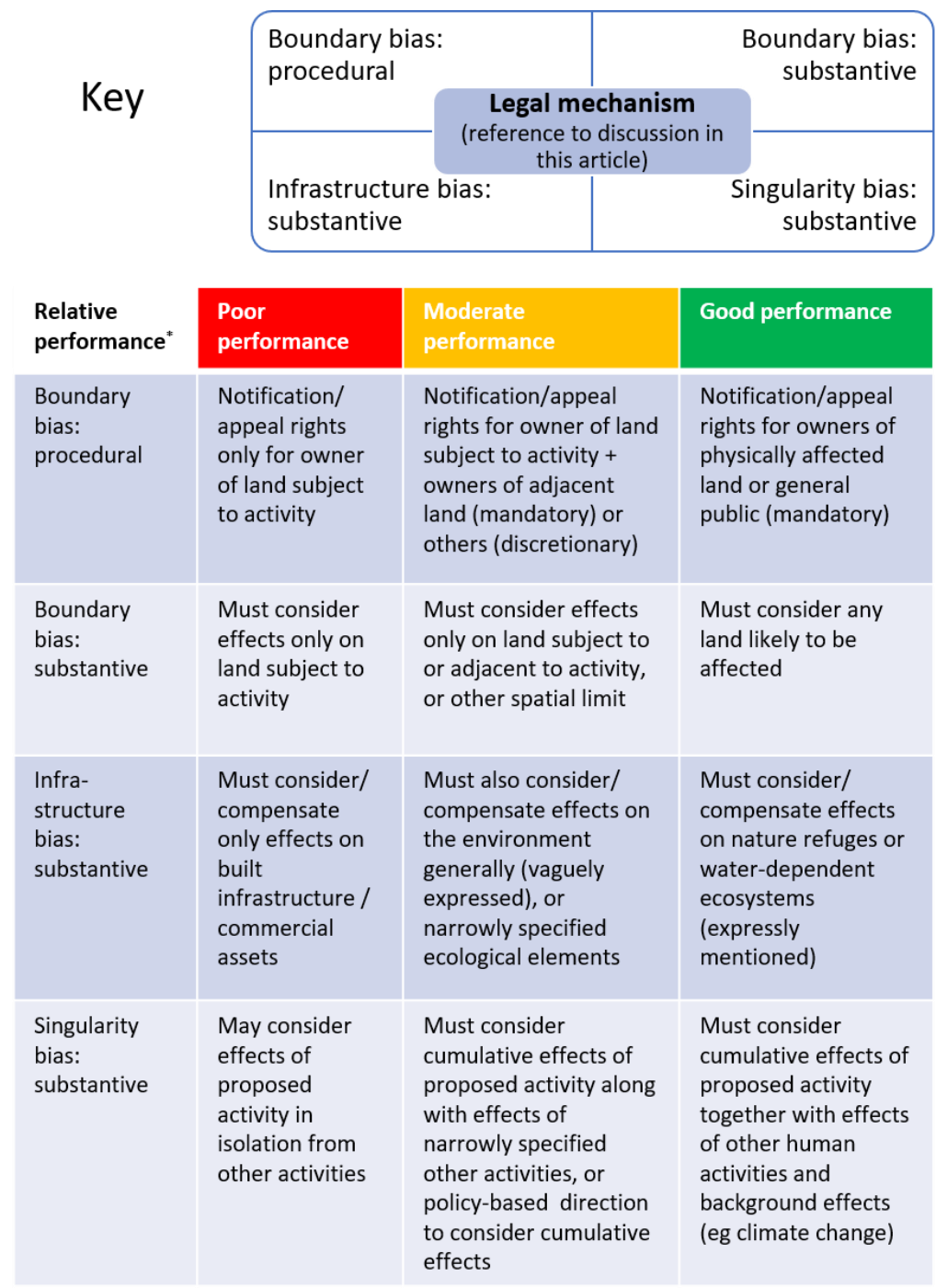

* Describes performance as the provision appears on paper, relative to other mechanisms in effect in Queensland (not intended to describe performance in absolute or empirical terms) 


\section{Area of law}

Legal mechanisms

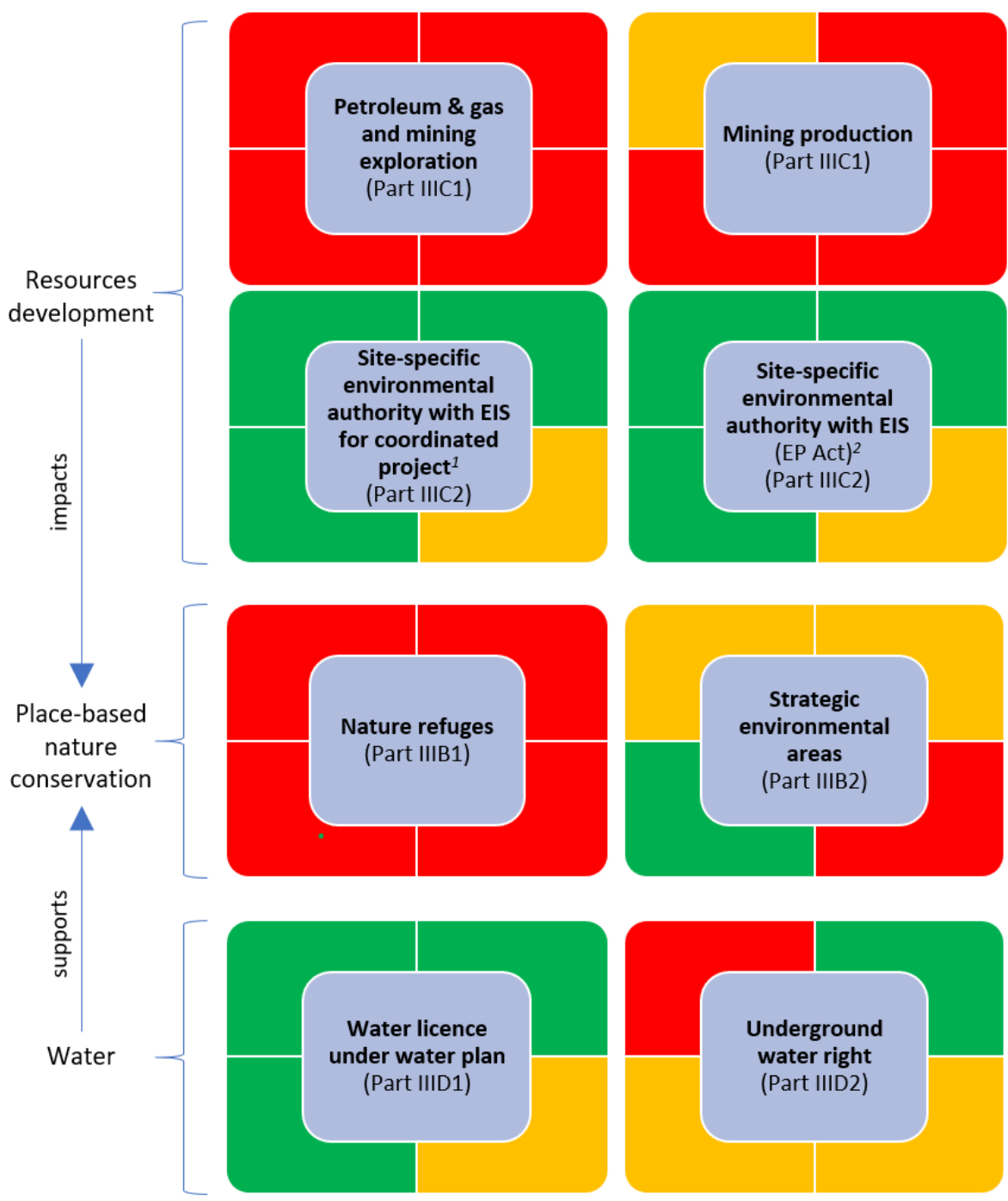

${ }^{1}$ Represents 'best case scenario' relative to EIA undertaken by the streamlined process for impact assessment reports

${ }^{2}$ Represents 'best case scenario' relative to more commonly used standard authorities 


\section{Notification and Appeal Rights for Private Conservation Landholders Potentially Affected by the Off-Site Effects of a Resources Activity (Procedural Boundary Bias)}

The upper left cell of each matrix diagram in Figure 1 summarises how a legal mechanism performs against the procedural dimension of the boundary bias the degree to which notification and appeal rights are available to landholders who may be affected by the impacts that a resources development may cause outside the development's boundaries. These cells show that these rights are quite constrained in relation to approvals under mining and petroleum laws, for projects in strategic environmental areas and in relation to underground water rights, but broader for approvals for coordinated projects, in relation to sitespecific environmental authorities, and for projects that require water licences for substantial activities. Laws exhibiting 'good' performance on this dimension do so on the basis of broad mandatory public notification. None of the laws reviewed here include a requirement to directly notify holders of non-adjacent lands that may be ecologically impacted by a resources project, even if the project operators have predicted, or might reasonably expect, those non-adjacent lands to experience environmental changes. This burdens nature refuge owners mindful of such threats with the task of keeping abreast of public notices of applications in newspapers and online, and the details of EISs, to assess the likelihood and significance of a threat. This is inefficient, at the very least, given that project proponents who analyse the spatial extent of the possible environmental impacts of their projects could identify potentially impacted parcels and notify parcel owners with relative ease. Even if a private conservation landholder has rigorous internal processes to identify project applications, publicly available EIS documents are not typically accompanied by modelling information that would be sufficient for that landholder to assess ecological risks to its parcel.

\section{Consideration of Effects on Private Conservation Land beyond the Resources Tenure (Substantive Boundary Bias)}

The upper right cell of each matrix diagram in Figure 1 summarises how a legal mechanism performs against the substantive dimension of the boundary bias the degree to which approvals processes consider off-site impacts of a resources activity on the land of private conservation landholders as a factor relevant to a decision whether or not to approve the activity or to apply conditions to it. Similar to the procedural boundary bias, these cells show that considerations are quite limited in relation to approvals under mining and petroleum laws, somewhat unclear for projects in the few spatially limited strategic environmental areas, and that the nature refuge law is not linked to other relevant laws and does not itself impose any relevant obligations. Considerations are broader for approvals for coordinated projects, in relation to environmental authorities (though specific 
references to private conservation lands are rare, sometimes unclear, and found in policy rather than law), projects that require water licences for substantial activities, and in relation to underground water rights (but only in relation to springs and within defined declared areas - as discussed below). From a regulatory perspective, then, some important laws are relatively well able to see beyond the boundaries of the resources tenure in considering potential impacts of the resources activity, though this vision does not apply equally across the state and for all resources projects.

\section{Consideration of Effects on Ecological Assets on Private Conservation Land Beyond the Resources Tenure (Infrastructure Bias)}

The lower left cell of each matrix diagram in Figure 1 summarises how a legal mechanism performs against the infrastructure bias - the degree to which approvals processes consider and protect against the off-site impacts of a resources activity on the ecological assets of private conservation landholders. Considering the legal mechanisms across the relevant areas of law together, it is evident that many mechanisms evidence significant infrastructure bias (resources exploration, mining production, underground water rights), and those that resist this bias tend to apply to narrow categories of resources developments (coordinated projects, site-specific environmental authorities, water licence requirements) or spatially limited areas (strategic environmental areas).

Importantly, no legal mechanism analysed here includes a requirement to specifically consider potential impacts on ecological assets on private conservation land, as distinct from ecological impacts (or certain narrow kinds of ecological impacts) more generally. ${ }^{247}$ This is risky given that decision-makers may overlook or lack good information about the value of privately held ecological assets. The lack of express legal attention to ecological assets on nature refuges is incongruous given that the state encourages and invests in private conservation land as an important element of its biodiversity protection strategy.

Visualising the legal analysis also shows that for a particular legal mechanism, a weakness in one dimension of potential bias can undermine strength in another dimension. In the case of underground water rights under the Water Act 2000 (Qld) ('Water Act'), the substantive boundary bias does not prevent the law from considering effects beyond tenure boundaries (upper right cell). However, an infrastructure bias (lower left cell) prevents these considerations from translating into comprehensive ecological considerations (including categories of GDEs beyond springs, such as terrestrial vegetation) or substantive protections. As a result, even though the underground water rights regime looks beyond artificial tenure boundaries, it cannot achieve an adequate level of

247 There is a limited exception to this in the policy-based terms of reference for EIS guidelines under the Environmental Protection Act (n 136): see above n 187-1878 and accompanying text. 
ecological protection. Equally, the positive aspects of site-specific environmental authorities are undermined by insufficient attention to cumulative effects (the singularity bias - see below) as well as limitations to the scope of use of sitespecific environmental authorities.

\section{Consideration of the Effects of a Single Resources Activity in Isolation from the Overlapping (Cumulative) Effects of Other Resources Activities (Singularity Bias)}

The lower right cell of each matrix diagram in Figure 1 summarises how a legal mechanism performs against the singularity bias - the degree to which the law directs a decision-maker to consider the cumulative environmental effects of the proposed activity together with the effects of other human activities, including climate change. No identified legal mechanism does this to an extent judged 'good'. Some legal mechanisms resist this bias to a moderate degree but fall short of 'good' because a direction to consider cumulative effects is contained in a brief policy mention rather than in law, supported by detailed guidelines. This is the case for projects requiring a site-specific environmental authority under the Environmental Protection Act, either as coordinated projects assessed by EIS under the State Development Act or by EIS under the Environmental Protection Act. Others fall short of 'good' because of the narrowness of cumulative effects assessment legally required to be undertaken. This is the case with the regime for underground water rights under the Water Act, which considers only cumulative effects on bores and springs, rather than GDEs generally. The pervasive weakness of cumulative effects considerations across these regimes marks this issue out for particular attention in reform efforts.

\section{StRengthening Protections For Private CONSERVATION LANDS}

Queensland's nature refuges are even more vulnerable than the problem of mining within their boundaries suggests. They are not expressly considered in regimes for dealing with the environmental harms of resources activities, despite the state recognising that their 'significant cultural and natural resources' deserve state financial and technical support, with the landholder agreeing to manage the land accordingly. ${ }^{248}$ This vulnerability could be remedied by amending legislation and regulations to correct the boundary, infrastructure and singularity biases that emerge strongly in laws at the intersection of conservation lands, resources and water. Existing good practices revealed by the analysis above, and drawn out here, provide Queensland precedents for doing so. In the 
shorter term, the analysis above reveals potential for non-regulatory change, for example through amending policy guidelines and agency templates. The analysis also exposes potential for nature refuge owners to use current laws to reduce their vulnerability to off-site resources developments.

Resisting the boundary bias at the procedural level would involve giving rights to be notified directly, comment on, and object to, the granting of relevant resources authorisations not just to the immediate landholder, but to all property interest holders within the area that might be affected by the application in relation to a project - or, even better, by a proposed decision to release land for tender for resources tenures. This would amount to legally shifting a view about 'affected persons' that is limited by the artificial boundaries of property tenures to one that is based on scientific evidence about potential physical effects. These science-informed boundaries may evolve with time as understanding about effects increases. For example, a preliminary view of the spatial scope of potential effects at the stage of a draft terms of reference for an EIS may, with the benefit of additional data collection and modelling, differ from what is understood by the time the draft EIS is produced. The spatial application of notice, comment and objection provisions should change accordingly to ensure that those potentially affected are alerted to this possibility and involved in decision-making processes. The current good practice of granting public comment rights in relation to EISs for coordinated projects and under the Environmental Protection Act could be extended to other regimes and improved by requiring direct notification of potentially affected persons, determined in a science-informed way, to reduce the burden on landholders to keep abreast of applications that may affect them. At minimum, as a matter of policy, government could institute a simple email sign-up list for landholders and interested parties to be informed of resources applications within a geographic area.

Similarly, resisting the boundary bias in terms of substantive protections would require uniformly considering whether the effects of a resource activity might extend beyond the resources tenure and immediately adjacent areas. This currently occurs under EISs for coordinated projects. Consistent with this good practice approach, damage caused outside the tenure boundaries by a resource activity should also be eligible for compensation. Reforms should also include regulating resources activities that have long-range effects on areas that currently have special environmental status, such as strategic environmental areas, as if they were located within the area (that is, requiring a regional interests development approval for an activity that is likely to affect a strategic environmental area even if it is located outside that area). ${ }^{249}$ The potential for an activity to affect a distant protected matter is long-established in the context of Commonwealth environmental law. ${ }^{250}$

See Part IIIB2.

Gerry M Bates, Environmental Law in Australia (LexisNexis Butterworths, $8^{\text {th }}$ ed, 2013) 361. 
Addressing the infrastructure bias involves more consistently applying the implicit understanding in the Nature Conservation Act and recent policy ${ }^{251}$ that private investment in ecological assets - valuable plants and animals - is just that: an investment. Damaging that investment is as important to the conservation landholder as damage to the investment of a resident or farmer in a house, fences, or livestock. Permanently damaging valuable ecological assets also damages more than private property: it impairs the common heritage of all Australians and, more prosaically, the government's co-investment in that heritage. Policy guidelines for terms of reference for EISs under the Environmental Protection Act provide support for specifically considering impacts on conservation properties outside the resources tenure and should be made mandatory and extended to other regimes, expressly calling attention to conservation land under the Nature Conservation Act.

At minimum, damage to investments in ecological assets should be treated in the same way as damage to built infrastructure. Opportunities to correct a current infrastructure bias arise in the land access code for resources authority holders (which only protects built infrastructure and livestock); the underground water obligations regime (which only provides for monitoring and protecting bores and springs, rather than GDEs more comprehensively); and the compensation regime applicable to resources authorities. Legislation ought also to refer specifically to nature refuges in the context of lists of statutory environmental considerations and key documents like environmental protection policies under the Environmental Protection Act, preferably accompanied by quantified standards for protecting GDEs. Expressly recognising nature refuges would be consistent with the broad definition of the 'environment' under the State Development Act and Environmental Protection Act, which includes the 'social, economic, aesthetic and cultural conditions' related to ecosystems.

Considering cumulative effects is not unknown to Queensland law. The guidelines for EISs for coordinated projects, underground water impact reports and the definition of environmental harm under the Environmental Protection Act are good current examples of this. However, more is needed to effectively combat the singularity bias. Clear guidelines are needed, ideally with regulatory status, mirroring the approach long taken in overseas jurisdictions ${ }^{252}$ and now also taken in management of the Great Barrier Reef. ${ }^{253}$ Those guidelines should also expressly call out conservation lands.

Nature refuge owners could also explore options to strengthen their protection from off-site resources activities. To confront the infrastructure bias, they should document the ways in which their operations rely on built infrastructure (for example, bores, modified springs, etc, used to support on-site

\footnotetext{
$251 \quad$ See above $\mathrm{n} 27$ and accompanying text.

252 See, eg, Considering Cumulative Effects under the NEPA (n 42).

253 See generally Great Barrier Reef Marine Park Authority, Reef 2050 Plan: Cumulative Impact Management Policy (Report, July 2018).
} 
reserve managers or provide supplementary water for ecological assets during drought) and document investments in restoring ecological assets. Further, they might themselves apply for groundwater licences for ecological purposes (either in situ, to support GDEs), or to provide supplementary water in the future, as a way to make concrete their interests in water resources that might otherwise be more difficult to defend. Holding groundwater licences for wildlife or environmental purposes is uncommon, but not unheard of, in both Australia and other jurisdictions. ${ }^{254}$

Nature refuge owners or sector leaders might address procedural weaknesses that could leave nature refuge owners unaware of nearby resources applications (for example, because they are not required to be directly notified) by aggregating public notices of applications and providing alerts to landholders within a reasonable distance of an application.

\section{$\mathrm{V}$ CONCLUSION}

Despite justifiably celebrated improvements in Queensland's environmental protection regime in relation to special wildlife reserves, its complex laws in relation to mining-related risks have not kept up with increasing reliance on private investment in ecological outcomes. Relevant laws tend to take a spatially limited view of potentially affected landholders in a way that does not reflect the scale of modern resources activities. They overlook the potential conservation purposes of landholdership, which are encouraged by government. They tend to ignore the implications of modern scientific evidence about the importance of groundwater to maintaining a broad suite of conservation values, and the potential for adverse effects to propagate over long distances through groundwater systems, unseen. These laws are also built on biases that keep the law focused on isolated impacts that are spatially proximate and concerned with built infrastructure rather than ecological assets. Unaddressed, these biases enable government to 'have its cake and eat it'. On the one hand, government may reduce or avoid public expenditure on national parks by encouraging private landholders to expend resources on public interest environmental outcomes for the long term. On the other hand, government overlooks the kind of protections that would secure those outcomes in the face of the sustained and compounding effects of a burgeoning resources industry that delivers short-term economic benefits.

254 See, eg, Department of Agriculture, Water and the Environment (Cth), 'Environmental Water Holdings', Managing Water for the Environment (Web Page) <https://www.environment. gov.au/water/cewo/about/water-holdings>; ND Cent Code § 61-04-02; Barton Springs/Edwards Aquifer Conservation District, Final Habitat Conservation Plan for Managed Groundwater Withdrawals from the Barton Springs Segment of the Edwards Aquifer (Report, 2018) 148, 164. 
The new legislative mechanism of the special wildlife reserve is to be lauded, but it should also be accompanied by honest reflection on the conflict inherent between conservation and resources development and appropriate legal mechanisms for addressing it. As a whole, Queensland's laws leave significant vulnerabilities for protected areas, and particularly those on private land, to longrange groundwater-related impacts caused by resources development. This conclusion emerges from analysing the 'best case' of the most rigorous legislative frameworks, from which most projects do not benefit. Ecosystems protected by nature refuge agreements and special wildlife reserves should be given special consideration in these regimes through (1) procedural protections that notify and seek submissions from landholders outside the tenure boundaries that may be affected by a project, and (2) substantive requirements to consider and mitigate these impacts, and, if necessary, compensate unforeseen impacts, analogous to the requirements that apply to the investments of agricultural and pastoral landholders. Avoiding and mitigating these impacts is not only vital to protect biodiversity now - it will be even more important in the future. In the Queensland government's words, '[a]s the effects of climate change increase, protected areas will become even more essential and at the core of how society, biodiversity and landscape processes change and adapt to new environmental conditions'. ${ }^{255}$ 